\title{
A Valuable Product of Microbial Cell Factories: Microbial Lipase
}

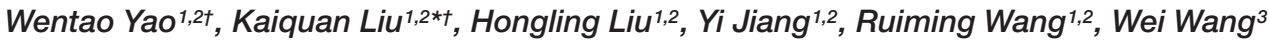 \\ and Tengfei Wang ${ }^{1,2 *}$
}

${ }^{1}$ State Key Laboratory of Biobased Material and Green Papermaking (LBMP), Qilu University of Technology (Shandong Academy of Sciences), Jinan, China, ${ }^{2}$ Key Laboratory of Shandong Microbial Engineering, College of Bioengineering, QiLu University of Technology (Shandong Academy of Sciences), Jinan, China, ${ }^{3}$ State Key Laboratory of Microbial Metabolism, School of Life Sciences and Biotechnology, Shanghai Jiao Tong University, Shanghai, China

OPEN ACCESS

Edited by:

Muhammad Bilal,

Huaiyin Institute of Technology, China

Reviewed by:

Marcelo Franco,

Universidade Estadual de Santa Cruz,

Brazil

Shuqi Guo,

Xi'an Jiaotong University, China

Long Liu,

Jiangnan University, China

Shaoqing Yang,

China Agricultural University, China

*Correspondence:

Tengfei Wang

wtf@qlu.edu.cn

Kaiquan Liu

liukq@qlu.edu.cn

${ }^{t}$ These authors have contributed equally to this work and share first

authorship

Specialty section:

This article was submitted to

Microbiotechnology,

a section of the journal

Frontiers in Microbiology

Received: 18 July 2021

Accepted: 26 August 2021

Published: 20 September 2021

Citation:

Yao W, Liu K, Liu H, Jiang Y, Wang $R$, Wang $W$ and Wang $T$ (2021) A Valuable Product of Microbial Cell

Factories: Microbial Lipase.

Front. Microbiol. 12:743377.

doi: 10.3389/fmicb.2021.743377
As a powerful factory, microbial cells produce a variety of enzymes, such as lipase. Lipase has a wide range of actions and participates in multiple reactions, and they can catalyze the hydrolysis of triacylglycerol into its component free fatty acids and glycerol backbone. Lipase exists widely in nature, most prominently in plants, animals and microorganisms, among which microorganisms are the most important source of lipase. Microbial lipases have been adapted for numerous industrial applications due to their substrate specificity, heterogeneous patterns of expression and versatility (i.e., capacity to catalyze reactions at the extremes of $\mathrm{pH}$ and temperature as well as in the presence of metal ions and organic solvents). Now they have been introduced into applications involving the production and processing of food, pharmaceutics, paper making, detergents, biodiesel fuels, and so on. In this mini-review, we will focus on the most up-to-date research on microbial lipases and their commercial and industrial applications. We will also discuss and predict future applications of these important technologies.

Keywords: lipase, microbial source, heterologous expression, industry application, future perspectives

\section{INTRODUCTION}

Lipases (EC 3.1.1.3), also known as triacylglycerol acyl hydrolase, are serine hydrolases that catalyze the removal of esterified fatty acids from complex compounds (Chandra et al., 2020). Lipases are important industrial enzymes that are used widely in various production strategies. Lipases are the third most commonly used enzyme class after proteases and amylases (Ulker et al., 2011). It could catalyze the hydrolysis of various forms of long-chain triacylglycerides to form free fatty acids and glycerol, and the synthesis of fatty acid glycerides based on fatty acids and glycerol, which is a class of carboxylic ester hydrolases (EC 3.1.1.X) (Geoffry and Achur, 2017).

Abbreviations: $\beta$-ME, beta-mercaptoethanol; AOT, di-octyl sulfosuccinate (Aerosol-OT); AOX, alcohol oxidase; CALB, Candida antarctica lipase B; CTAB, cetyl trimethyl ammonium bromide; DEPC, diethylpyrocarbonate; DMSO, dimethyl sulfoxide; DTNB, 5,5'-dithio-bis-[2-nitrobenzoic acid]; DTT, dithiothreitol; EDAC, 1-ethyl-3-(3-dimethyl aminopropyl) carbodiimide; EDTA, ethylene diamine tetraacetic acid; ELISAs, Enzyme-Linked Immunosorbent Assays; LPL, lipoprotein lipase; LPS, lipopolysaccharide; OTAB, octadecyl trimethyl ammonium bromide; pCMBA, para-Chloromethyl benzoic acid; PEG, polyethylene glycol; PMSF, phenyl methane sulfonyl fluoride; RIAs, radioimmunoassays; SDS, sodium dodecyl sulfate; WRK, Woodward's Reagent $\mathrm{K}$. 
Lipases are divided into three categories based on their location and substrate specificity; these include non-specific lipases, 1, 3-specific lipases, and fatty-acid specific lipases. Nonspecific lipases catalyze the hydrolysis of triglycerides into free fatty acids and glycerol via monoglyceride and diglyceride intermediates; these enzymes are capable of removing fatty acids from any of the three esterified sites of the original substrate, although hydrolysis of the monoglyceride and diglyceride intermediates proceeds more rapidly than that of the original triglyceride substrate (Ferreira-Dias et al., 2013). The 1, 3-specific lipases catalyze the release of fatty acids from the 1 and 3 carbon sites of the of triglyceride substrate; they are not capable of performing hydrolysis at the middle, or second ester bond. The 1, 3-specific lipases promote hydrolysis of triglycerides into monoglycerides at a more rapid rate than performed by nonspecific lipases (Kavadia et al., 2018; López-Fernández et al., 2019; Gao et al., 2020). By contrast, fatty-acid-specific lipases demonstrate substrate selectivity; these enzymes target longchain fatty acids with cis-double bonds between C-9 and C-10 (Kapoor and Gupta, 2012).

Lipases that catalyze the hydrolysis of triacylglycerol into fatty acids and glycerol, as well as into monoacylglycerol and diacylglycerol can also be employed to promote both esterification and transesterification reactions in both organic or inorganic solvents (Mouad et al., 2016; Jiao et al., 2018; Avhad and Marchetti, 2019). Among the properties of this environmentally friendly, or "green" catalyst, lipase has high catalytic efficiency, can function under comparatively mild reaction conditions, involves no coenzymes or other cofactors or by-products; as such, it is in wide use in various industrial fields including food, pharmaceutical, paper, detergent, and biodiesel production (Figure 1; Borowiecki et al., 2017; Dumorne et al., 2017; Sadaf et al., 2018; Vanleeuw et al., 2019).

With the development of genetic engineering technologies, more in-depth and comprehensive research reports have been published that focus on lipase gene expression, protein structure and function as well as its mechanism of action at the molecular level. Application of molecular cloning technologies facilitated the generation of systems for heterologous expression of microbial-derived lipases in Escherichia coli, Bacillus subtilis, Pichia pastoris, and Saccharomyces cerevisiae. Current research efforts focus on the screening of various lipase strains, the modification of existing lipase genes, analysis of modified lipase function, and the broader applicability of lipases in industrial settings.

This review discusses the research status of microbial lipase, discusses the main sources and expression of microbial lipase, lists the effects of physical and chemical factors on microbial lipase, and summarizes the latest research on microbial lipase and its commercial and industrial applications.

\section{SOURCE OF MICROBIAL LIPASES}

The earliest lipase studied (in the 1830s) was an enzyme preparation isolated from rabbit pancreas; interestingly, plantderived lipase was not discovered until the 1970s. Lipases derived from microbial sources were first identified early in the 20th century (Jaeger et al., 1994). Until recent years, metagenomics lipases and artificially designed lipases have gradually appeared in people's vision (Tang et al., 2017; Cen et al., 2019; Almeida et al., 2020; Verma et al., 2021).

Lipases can be identified in many forms and variants in animals, plants and microorganisms (Sarmah et al., 2017); the microbial lipases are notably diverse in nature (Gupta et al., 2004). Lipase activity is of central importance in all living organisms, as it modulates critical physiologic processes involved in digestion and absorption, as well as fat and lipoprotein metabolism (Winkler et al., 1990).

Compared with animals and plants, microorganisms encompass a wide variety of species, undergo rapid growth and reproduction, are typically easy to manipulate experimentally, and can be associated with significant genetic variation. Microbial lipases have received extensive attention in industrial applications due to its selectivity, stability and wide substrate specificity (Kumar et al., 2016). Furthermore, lipases produced by some microorganisms that live in extreme habitats have unique properties that are often more conducive for industrial production (Verma et al., 2021). Most lipases identified in microorganisms are secretory extracellular enzymes; they can be isolated at high purity and are thus suitable for mass production. As such, microbial lipases are the main source of industrial enzymes and present important value as well with respect to theoretical research.

Among microorganisms, lipase is most abundant in bacteria, fungi, and yeast. The most common bacterial sources for lipases include Bacillus spp., Pseudomonas spp., Staphylococcus sp., and Burkholderia sp. (Bharathi and Rajalakshmi, 2019; Priyanka et al., 2019). Bacterial lipase catalyzed the most types of hydrolytic reactions and the highest levels of activity; the bacterial enzymes were also among the most stable. Of this group, the lipase isolated from Pseudomonas spp. had the overall best performance (Panizza et al., 2013). Fungal lipases have been used extensively in a variety of biotechnology applications due to their stability, specificity, and ease of production. Among these, lipases isolated from Thermomyces lanuginosus, Rhizopus oryzae, and Aspergillus niger all have important industrial value. In yeast, lipases of the genus Candida have been used for production and also for research; among these are lipases isolated from Candida antarctica and Candida rugosa (Sarmah et al., 2017).

\section{IDENTIFICATION OF LIPASE ACTIVITY IN MICROORGANISMS AND ANALYSIS OF ITS ENZYMATIC PROPERTIES}

\section{Determination of Lipase Activity}

Many methods have been used to identify lipase activity; these include both immunological and physicochemical methods.

\section{Immunological Methods}

Immunological methods can be used to quantify lipases in biological solvents, independent of its enzymatic activity 


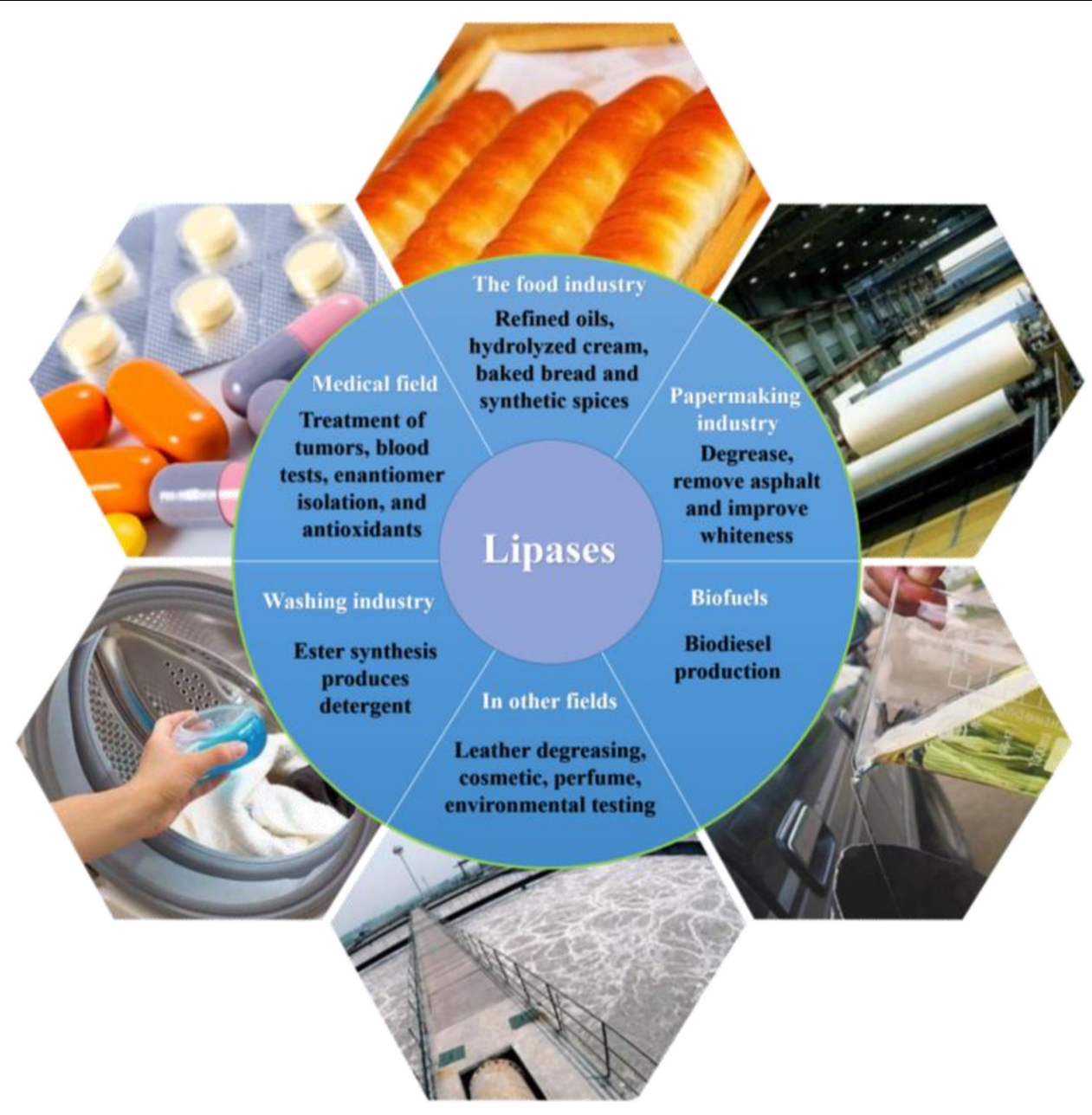

FIGURE 1 | Various industrial applications that feature microbial lipases.

(Sarmah et al., 2018). Immunological methods used for this purpose include immunoblot (Western blot) analysis (Bezzine et al., 1998), radioimmunoassays (RIAs), and EnzymeLinked Immunosorbent Assays (ELISAs; Miyashita et al., 2017). ELISAs are highly sensitive and specific for this purpose. Dati and Grenner detected and quantified pure lipase with this methodology (Dati and Grenner, 1984); Miyashita et al. has established a new ELISA method using newly generated monoclonal Abs (MoAbs) for quantification of serum hepatic triglyceride (TG) lipase (HTGL), as well as postheparin plasma hepatic triglyceride lipase (PHP-HTGL; Miyashita et al., 2017). Immunological methods can be timeconsuming to develop given the months required for antibody generation; these methods have some limitations with respect to practical application.

\section{Physical and Chemical Methods}

Physical and chemical methods include plate methods (Momsen and Brockman, 1997), colorimetric methods (Hiol et al., 1999), and titration methods (Singh and Mukhopadhyay, 2012). The plate assay is a rapid, qualitative detection method, that was developed in 1987 by Kouker and Jaeger using Rhodamine B as an indicator (Kouker and Jaeger, 1987). This method facilitated the detection of the bacterial lipase under UV irradiation, as substrate hydrolysis resulted in the formation of a fluorescent orange halo, with the degree and extent of the activity reflected in its diameter. Although this method is simple, it is not precisely quantitative, and as such is more commonly used for qualitative detection only.

The colorimetric method is more accurate, reliable, and sensitive, but it requires specific equipment and complicated procedures. Titration is a system that involves substrate, buffer, and enzyme solution (Dharmsthiti et al., 1998). Reactions are carried out at specific temperatures and $\mathrm{pH}$; they are then terminated with 95\% ethanol. After adding indicators, the reaction is titrated with a standard alkaline solution. This method is simple and generates results rapidly. Although this procedure is associated with some errors, it is still widely used in practice.

The common substrates used to detect lipase activity by physicochemical methods include triglycerides and olive oil (Sri Kaja et al., 2018). Other versions of this assay feature synthetic or semi-synthetic triglycerides, chromogenic substrates, 
or radioactive tracer substrates. Given the cost of trioleate glyceride, olive oil is typically used as a substrate; olive oil contains more than $70 \%$ oleic acid, is comparatively inexpensive, and is widely available (Vorderwülbecke et al., 1992).

\section{Enzymatic Properties of Microbial Lipases}

Lipase catalyzes a variety of reactions; however, physical and chemical factors associated with these reactions can have a significant impact on enzyme activity. These factors include temperature, $\mathrm{pH}$, as well as the presence of metal ions, organic solvents, and surfactants. Lipases from various microorganisms as well as different lipases within a single strain show great differences with respect to physical and chemical properties; as such, it is of critical importance and great value to identify the optimal enzyme and critical conditions for each industrial application. The properties of several characterized microbial lipases are summarized in Table $\mathbf{1 .}$

\section{Optimal Catalytic Temperatures for Microbial Lipases}

Temperature is an important parameter when determining enzyme activity. Various lipases exhibit different thermal stabilities due to structural diversity. For example, a psychrophilic lipase from Bacillus F19L strain exhibited peak enzyme activity at $10{ }^{\circ} \mathrm{C}$; it maintained $80 \%$ of its peak when the temperature shifted to 5 (Goomber et al., 2016). Similarly, a lipase derived from Halocynthiibacter arcticus displayed a temperature optimum of $20{ }^{\circ} \mathrm{C}$. And, HaSGNH1 exhibited high relative activities at low temperatures, retaining $\sim 70 \%$ of its maximum activity even at $0{ }^{\circ} \mathrm{C}$ (Le et al., 2020). A sn-1,3 extracellular lipase derived from $A$. niger GZUF36 has an optimal reaction temperature of $35{ }^{\circ} \mathrm{C}$ and the enzyme activity dropped when the reaction temperature was beyond $50{ }^{\circ} \mathrm{C}$ (Xing et al., 2020). Similarly, a lipase derived from Bacillus licheniformis NCU CS-5, has an optimal temperature at $40^{\circ} \mathrm{C}$; its activity is relatively stable when the temperature is maintained between 5 and $55^{\circ} \mathrm{C}$ (Zhao et al., 2021). An interesting lipase was isolated from T. lanuginosus that is both heat and organic solvent resistant (lipase NS-40116). The optimal temperature for this lipase is $60{ }^{\circ} \mathrm{C}$; enzyme maintained at $60{ }^{\circ} \mathrm{C}$ for under $24 \mathrm{~h}$ retains $90 \%$ of its activity (Facin et al., 2018). A thermophilic lipase from Burkholderia ubonensis SL4 , has an optimal temperature at $65{ }^{\circ} \mathrm{C}$, and maintains good stability when held at 50-55 ${ }^{\circ} \mathrm{C}$ (Yang et al., 2016). Likewise, a thermophilic lipase derived from Janibacter sp. R02 has an optimal temperature of $80^{\circ} \mathrm{C}$ and maintains maximum enzyme activity between 50 and $90{ }^{\circ} \mathrm{C}$ (Castilla et al., 2016).

\section{Optimal pH for Microbial Lipases}

The optimal pH of microbial lipase is generally neutral ( $\mathrm{pH} 7.0$ ); there is no direct relationship between optimal $\mathrm{pH}$ and microbial species, but specific $\mathrm{pH}$ does have an association with the growth environments of specific microorganisms. The appropriate $\mathrm{pH}$ value is of critical importance for optimal lipase activity. For different lipases, the appropriate $\mathrm{pH}$ value can vary greatly.
The optimum $\mathrm{pH}$ of a solvent-resistant lipase from Micrococcus luteus EMP48-D was 5.0; enzyme activity significantly decreased up to $\mathrm{pH} 6.0$ and reducing continuously from $\mathrm{pH} 6.0$ to $\mathrm{pH} 10.0$, although was more than $85 \%$ of the initial activity of LipEMP48-D after incubation for $120 \mathrm{~min}$ at $40{ }^{\circ} \mathrm{C}$ (Adina et al., 2021). The heat and organic solvent-resistant lipase NS-40116 from T. lanuginosus displays highest activity at $\mathrm{pH}=7.0$ and maintains stability between pH 5.0-9.0 (Facin et al., 2018). Another lipase from T. lanuginosus exhibits an optimum $\mathrm{pH}$ of 8.5 , although high activity is maintained within the $\mathrm{pH}$ range of 8.0-10.0 (Kumar et al., 2019). A lipase derived from R. oryzae revealed an optimum pH of 9.0 (Asmat et al., 2018), although another lipase from Streptomyces bacillaris exhibited an optimum $\mathrm{pH}$ of 9.0, and high stability between $\mathrm{pH}$ values of 8.0-9.0 (Gao et al., 2021). A lipase from Aeribacillus pallidus has an optimal $\mathrm{pH}$ value of 10.0 , and was stable within a range of $\mathrm{pH}$ values from 9.0 to 11.0 at $40^{\circ} \mathrm{C}$; enzyme activity was maintained at $100 \%$ after $1 \mathrm{~h}$ under these conditions. However, the GPL retained $80 \%$ and $71 \%$ when it is respectively incubated at $\mathrm{pH} 8$, pH 7 (Ktata et al., 2019).

Interestingly, a lipase isolated from Candida viswanathii exhibited its highest activity at $\mathrm{pH}$ of 4.0 ; at $\mathrm{pH} 2.0-3.0$, the enzyme activity was reduced to $15-40 \%$, although $80 \%$ and $90 \%$ of its activity was maintained at $\mathrm{pH}$ values of 3.5 and 4.5 , respectively. At $\mathrm{pH}$ values $>6.5$, the activity decreased although a second $\mathrm{pH}$ maximum at 8.0 was observed (Almeida et al., 2018). However, a lipase from $A$. niger exhibited its highest activity at $\mathrm{pH} 4.0$, with $90 \%$ of this activity maintained at higher $\mathrm{pH}$ values (Zubiolo et al., 2014).

\section{Effects of Metal ions on Microbial Lipases}

The catalytic activity of lipase can be altered in the presence of metal ions; microbial lipases exhibit a varying tolerance to metal ions. For example, a lipase derived from B. ubonensis SL-4 is activated by $\mathrm{Ca}^{2+}$ and $\mathrm{Mn}^{2+}$ ions, while $\mathrm{Mg}^{2+}, \mathrm{Co}^{2+}$, $\mathrm{Cu}^{2+}, \mathrm{Pb}^{2+}, \mathrm{Al}^{3+}$ and $\mathrm{Fe}^{3+}$ strongly inhibit its activity (Yang et al., 2016). The organic solvent-tolerant lipase from Geobacillus stearothermophilus $\mathrm{AH} 22$ was found to be activated by $\mathrm{Co}^{2+}$, $\mathrm{Cu}^{2+}$ and $\mathrm{Mn}^{2+}$, while $\mathrm{Zn}^{2+}$ and $\mathrm{Hg}^{2+}$ inhibited its activity (Ekinci et al., 2016). The activity of a lipase derived from Paenibacillus pasadenensis CS0611 was strongly activated in $\mathrm{Ca}^{2+}$ and $\mathrm{Mg}^{2+}$, and its activity was as high as $208 \%$ and $146 \%$, while $\mathrm{Zn}^{2+}, \mathrm{Fe}^{2+}, \mathrm{Co}^{2+}, \mathrm{Mn}^{2+}$ and $\mathrm{Fe}^{3+}$ inhibited its activity (Gao et al., 2018). Interestingly, $\mathrm{Ca}^{2+}$ and $\mathrm{Mg}^{2+}$ promote the activity of a lipase from Serratia liquefaciens, while $\mathrm{Zn}^{2+}$ and $\mathrm{Fe}^{2+}$ are both inhibitory factors (Han et al., 2017).

\section{Effects of Surfactants on Microbial Lipases}

Microbial lipases are typically activated at the organic-aqueous solvent interfaces; as such, surfactants have significant influence on their activity.

For example, a lipase derived from B. ubonensis SL-4 was activated by Tween-20, Tween-40, Tween-60, Tween-80, Triton X-100, and cetyl trimethyl ammonium bromide (CTAB), 
TABLE 1 | Some enzymatic properties of microbial lipase.

\begin{tabular}{|c|c|c|c|c|c|c|}
\hline \multirow[t]{2}{*}{ Lipase source } & \multirow[t]{2}{*}{$\begin{array}{l}\text { Optimal } \\
\text { temperature }\end{array}$} & \multirow[t]{2}{*}{$\begin{array}{l}\text { Optimal } \\
\text { pH }\end{array}$} & \multirow[t]{2}{*}{$\begin{array}{l}\text { Substrate } \\
\text { specificity }\end{array}$} & \multicolumn{2}{|c|}{$\begin{array}{l}\text { Effects of ions, organic solvents, surfactants and other } \\
\text { compounds on lipase activity }\end{array}$} & \multirow[t]{2}{*}{ References } \\
\hline & & & & Promote & Inhibition & \\
\hline $\begin{array}{l}\text { Metagenomic } \\
\text { library }\end{array}$ & $74^{\circ} \mathrm{C}$ & 7.8 & $\begin{array}{l}\text { short-chain } \\
(C \leq 6) \text { and } \\
\text { long-chain fatty } \\
\text { acids }(C \geq 12)\end{array}$ & $\begin{array}{l}\mathrm{Hg}^{2+}, 1 \% \text { Methanol, } 1 \% \\
\text { Ethanol }\end{array}$ & $\begin{array}{l}\mathrm{Cu}^{2+}, \mathrm{Fe}^{2+}, \mathrm{Ca}^{2+}, \mathrm{Co}^{2+}, \mathrm{Mg}^{2+}, 15 \% \\
\text { Methanol,15\% Ethanol,15\% Isopropanol }\end{array}$ & Tang et al., 2017 \\
\hline Bacillus F19L & $10^{\circ} \mathrm{C}$ & 7.0 & $\begin{array}{l}\text { pNP-esters of } \\
\text { shorter chain }\end{array}$ & - & - & $\begin{array}{l}\text { Goomber et al., } \\
2016\end{array}$ \\
\hline $\begin{array}{l}\text { Halocynthiibacter } \\
\text { arcticus }\end{array}$ & $20^{\circ} \mathrm{C}$ & 8.0 & $\begin{array}{l}\text { p-nitrophenyl } \\
\text { butyrate (p-NB, } \\
\text { C4) }\end{array}$ & $0.5-1.0 \mathrm{M} \mathrm{Na}^{+}$ & 10\% Ethanol,Triton X-100,SDS,Urea & Le et al., 2020 \\
\hline $\begin{array}{l}\text { Aspergillus niger } \\
\text { GZUF36 }\end{array}$ & $35^{\circ} \mathrm{C}$ & 4.0 & - & - & - & Xing et al., 2020 \\
\hline $\begin{array}{l}\text { Bacillus } \\
\text { licheniformis NCU } \\
\text { CS-5 }\end{array}$ & $40^{\circ} \mathrm{C}$ & 8.0 & $\begin{array}{l}\text { Medium- and } \\
\text { long-chain fatty } \\
\text { acids (C6-C18) }\end{array}$ & $\begin{array}{l}\mathrm{Mg}^{2+}, \mathrm{K}^{+}, \mathrm{Na}^{+} \\
\mathrm{Ca}^{2+}, \mathrm{Al}^{2+}, \mathrm{Fe}^{3+} \\
\text { Glycerol,SDS, Tween-20, Tween- } \\
\text { 60,Tween-80,CTAB }\end{array}$ & $\begin{array}{l}\mathrm{Mn}^{2+}, \mathrm{Zn}^{2+}, \mathrm{Cu}^{2+}, \mathrm{Co}^{2+}, \mathrm{Sn}^{2+}, \text { Methanol, } \\
\text { Ethanol,Acetonitrile,Dimethyl sulfoxide,Acetone } \\
\text { Ethyl acetate, Tetrahydrofuran,Pyridine,Urea, } \\
\text { DTT,EDTA,NaF, } \mathrm{Na}_{3} \mathrm{VO}_{4}, \mathrm{PMSF}, \mathrm{H}_{2} \mathrm{O}_{2}\end{array}$ & Zhao et al., 2021 \\
\hline $\begin{array}{l}\text { Burkholderia } \\
\text { ubonensis SL-4 }\end{array}$ & $65^{\circ} \mathrm{C}$ & 8.5 & $\begin{array}{l}\text { Medium long } \\
\text { chain pNP- } \\
\text { esters(C8-C16) }\end{array}$ & $\begin{array}{l}\mathrm{Ca}^{2+}, \mathrm{Mn}^{2+}, \text { Triton } \\
\text { X-100,Tween-60,Ethylene } \\
\text { Glycol }\end{array}$ & $\begin{array}{l}\mathrm{Zn}^{2+}, \mathrm{Al}^{3+}, \mathrm{EDTA}, \mathrm{SDS}, \mathrm{PMSF}, \mathrm{DTT} \\
\mathrm{N} \text {-butanol,N-hexanol }\end{array}$ & Yang et al., 2016 \\
\hline Janibacter sp. R02 & $80^{\circ} \mathrm{C}$ & $8.0 \sim 9.0$ & MUF-butyrate & $\mathrm{Na}^{+} / \mathrm{K}^{+}$, Combination,Urea & $\begin{array}{l}\mathrm{Mn}^{2+}, \mathrm{Co}^{2+}, \mathrm{Cu}^{2+}, \mathrm{Ni}^{2+}, \mathrm{Fe}^{2+}, \mathrm{SDS} \text {, Triton } \\
\mathrm{X}-100\end{array}$ & Castilla et al., 2016 \\
\hline $\begin{array}{l}\text { Micrococcus } \\
\text { luteus EMP48-D }\end{array}$ & - & 5.0 & olive oil & $\begin{array}{l}\mathrm{Fe}^{2+} \text {,Isopropanol,Butanol, } \\
\text { Ethanol,Acetonitrile,Methanol }\end{array}$ & $\begin{array}{l}\mathrm{K}^{+}, \mathrm{Mg}^{2+}, \mathrm{Mn}^{2+}, \mathrm{Na}^{+}, \mathrm{Ca}^{2+}, \mathrm{N}-\text { hexane, } \mathrm{N}- \\
\text { heptane }\end{array}$ & Adina et al., 2021 \\
\hline $\begin{array}{l}\text { Thermomyces } \\
\text { lanuginosus }\end{array}$ & $60^{\circ} \mathrm{C}$ & 7.0 & - & - & - & Facin et al., 2018 \\
\hline $\begin{array}{l}\text { Thermomyces } \\
\text { lanuginosus }\end{array}$ & $60^{\circ} \mathrm{C}$ & 8.5 & - & - & - & Kumar et al., 2019 \\
\hline Rhizopus oryzae & $45^{\circ} \mathrm{C}$ & 9.0 & - & - & - & Asmat et al., 2018 \\
\hline $\begin{array}{l}\text { Streptomyces } \\
\text { bacillaris }\end{array}$ & $45^{\circ} \mathrm{C}$ & 9.0 & $\begin{array}{l}\text { p-nitrophenyl } \\
\text { phosphate } \\
\text { (p-NPP) }\end{array}$ & 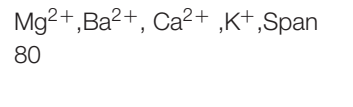 & $\begin{array}{l}\mathrm{Zn}^{2+}, \mathrm{Ni}^{+}, \text {EDTA, TritonX-100, Tween-80, Tween- } \\
\text { 20,SDS }\end{array}$ & Gao et al., 2021 \\
\hline $\begin{array}{l}\text { Aeribacillus } \\
\text { pallidus }\end{array}$ & $65^{\circ} \mathrm{C}$ & 10.0 & $\begin{array}{l}\text { short chain } \\
\text { triacylglycerols }\end{array}$ & $\mathrm{Ca}^{2+}, \mathrm{Zn}^{2+}, \mathrm{Fe}^{2+}, \mathrm{Mg}^{2+}$ & $\begin{array}{l}\text { EDTA,PMSF, } \beta \text {-mercaptoethanol, } \\
\text { SDS,Isooctane,Hexane, chloroform,Urea, } \\
\text { Guanidine Hydrochloride }\end{array}$ & Ktata et al., 2019 \\
\hline $\begin{array}{l}\text { Candida } \\
\text { viswanathii }\end{array}$ & $45^{\circ} \mathrm{C}$ & 4.0 & $\begin{array}{l}\text { Long chain } \\
\text { methyl ester } \\
\text { substrate(C16) }\end{array}$ & $\mathrm{Mn}^{2+}, \mathrm{DTT}, \beta$-mercaptoEthanol & $\begin{array}{l}\mathrm{Co}^{2+}, \mathrm{Hg}^{2+}, \text { PMSF,EDTA,SDS, Tween-20, } \\
\text { Tween-80, Sodium deoxycholate }\end{array}$ & Almeida et al., 2018 \\
\hline $\begin{array}{l}\text { Geobacillus } \\
\text { stearothermophilus } \\
\mathrm{AH} 22\end{array}$ & $50^{\circ} \mathrm{C}$ & $8.0 \sim 9.0$ & $\begin{array}{l}\text { Short chain } \\
\text { methyl ester } \\
\text { substrate(C4) }\end{array}$ & $\mathrm{Co}^{2+}, \mathrm{Mn}^{2+}, \mathrm{Cu}^{2+}$ & $\mathrm{Hg}^{2+}, \mathrm{Zn}^{2+}, \mathrm{SDS}$, Triton X-100 & Ekinci et al., 2016 \\
\hline $\begin{array}{l}\text { Paenibacillus } \\
\text { pasadenensis } \\
\text { CS0611 }\end{array}$ & $50^{\circ} \mathrm{C}$ & 7.0 & $\begin{array}{l}\text { pNP-esters } \\
\text { (C8) }\end{array}$ & $\begin{array}{l}\mathrm{Ca}^{2+}, \mathrm{Mg}^{2+}, \mathrm{Cu}^{2+}, \text { Triton } \\
\text { X-100,Tween- } 80\end{array}$ & $\begin{array}{l}\mathrm{Zn}^{2+}, \mathrm{Fe}^{2+}, \mathrm{Co}^{2+}, \mathrm{Mn}^{2+}, \mathrm{Fe}^{3+} \\
\text { EDTA,PMSF, } \beta \text {-mercaptoethanol,SDS }\end{array}$ & Gao et al., 2018 \\
\hline $\begin{array}{l}\text { Serratia } \\
\text { liquefaciens }\end{array}$ & $45^{\circ} \mathrm{C}$ & 8.0 & - & $\mathrm{Ca}^{2+}, \mathrm{Mg}^{2+}$, Tween-20 & $\mathrm{Zn}^{2+}, \mathrm{Fe}^{2+}, \mathrm{EDTA}, \mathrm{SDS}$ & Han et al., 2017 \\
\hline $\begin{array}{l}\text { Pseudomonas } \\
\text { aeruginosa ES3 }\end{array}$ & $40^{\circ} \mathrm{C}$ & $9.0 \sim 10.0$ & - & $\mathrm{Ca}^{2+}$, sodium cholate & $\mathrm{Cd}^{2+}, \mathrm{Cu}^{2+}$, lodoacetic acid,PMSF & Sarac et al., 2015 \\
\hline $\begin{array}{l}\text { Bacillus } \\
\text { halodurans }\end{array}$ & $60^{\circ} \mathrm{C}$ & 9.0 & $\begin{array}{l}\text { mid chain } \\
\text { length pNP acyl } \\
\text { esters }\end{array}$ & $\begin{array}{l}\mathrm{Cd}^{2+}, \mathrm{Ni}^{2+}, \mathrm{Fe}^{3+} \\
\mathrm{pCMBA}, \mathrm{DTNB}\end{array}$ & $\mathrm{Ba}^{2+}, \mathrm{Fe}^{2+}, \mathrm{Pb}^{2+}, \mathrm{DEPC}, \mathrm{EDAC}, \mathrm{PMSF}, \mathrm{WRK}$ & $\begin{array}{l}\text { Dua and Gupta, } \\
2017\end{array}$ \\
\hline $\begin{array}{l}\text { Rhizomucor miehei } \\
\text { NRRL5282 }\end{array}$ & $40^{\circ} \mathrm{C}$ & 7.0 & $\begin{array}{l}\text { Medium long } \\
\text { chain } \\
\text { pNP-esters }\end{array}$ & $\mathrm{Mg}^{2+}$ & $\mathrm{Hg}^{2+}, \mathrm{NBS}, \mathrm{SDS}, \mathrm{Hexanol,Butanol}$ & Takó et al., 2017 \\
\hline $\begin{array}{l}\text { Pseudomonas } \\
\text { moraviensis M9 }\end{array}$ & $65^{\circ} \mathrm{C}$ & 8.0 & $\begin{array}{l}\text { Medium long } \\
\text { chain pNP- } \\
\text { esters(C8-C16) }\end{array}$ & $\mathrm{Ca}^{2+}, \mathrm{Sr}^{2+}, \mathrm{Mn}^{2+}, \mathrm{Ba}^{2+}$ & $\begin{array}{l}\mathrm{Cu}^{2+}, \mathrm{Zn}^{2+}, \mathrm{Co}^{2+}, \mathrm{Ni}^{2+}, \text { EDTA, Glycerin, } \\
\text { PEG-400,PEG-600 }\end{array}$ & Yang et al., 2015a \\
\hline
\end{tabular}


TABLE 1 | (Continued)

\begin{tabular}{|c|c|c|c|c|c|c|}
\hline \multirow{3}{*}{ Lipase source } & \multirow{3}{*}{$\begin{array}{l}\text { Optimal } \\
\text { temperature }\end{array}$} & \multirow{3}{*}{$\begin{array}{l}\text { Optimal } \\
\text { pH }\end{array}$} & \multirow{3}{*}{ Substrate specificity } & \multirow{2}{*}{\multicolumn{2}{|c|}{ Effects of ions, organic solvents, surfactants and other }} & \multirow[t]{3}{*}{ References } \\
\hline & & & & & & \\
\hline & & & & Promote & Inhibition & \\
\hline $\begin{array}{l}\text { Pseudomonas sp. } \\
\text { R0-14 }\end{array}$ & $60^{\circ} \mathrm{C}$ & 8.5 & $\begin{array}{l}\text { Medium and short chain long } \\
\text { pNP-esters }\end{array}$ & $\mathrm{Ca}^{2+}, \mathrm{Sr}^{2+}, \mathrm{Ba}^{2+}$ & $\begin{array}{l}\mathrm{Cu}^{2+}, \mathrm{Zn}^{2+}, \mathrm{Mg}^{2+}, \mathrm{Ni}^{2+}, \mathrm{EDTA}, \text { Ethyl } \\
\text { Alcohol, Glycerin,DMSO }\end{array}$ & Yang et al., 2015b \\
\hline $\begin{array}{l}\text { Pseudomonas } \\
\text { protegens Pf-5 }\end{array}$ & $55^{\circ} \mathrm{C}$ & 9.5 & $\begin{array}{l}\text { Medium and short chain long } \\
\text { pNP-esters }\end{array}$ & $\begin{array}{l}\mathrm{Mg}^{2+}, \mathrm{Ca}^{2+}, \mathrm{Mn}^{2+} \\
\mathrm{Ba}^{2+}, \mathrm{K}^{+}, \mathrm{Na}^{+}\end{array}$ & $\mathrm{Fe}^{3+}, \mathrm{Zn}^{2+}, \mathrm{Cu}^{2+}, \mathrm{EDTA}$ & Zha et al., 2014 \\
\hline $\begin{array}{l}\text { Thermomyces } \\
\text { Lanuginosus }\end{array}$ & - & - & Short-stranded pNP-esters & - & - & Xin et al., 2017 \\
\hline $\begin{array}{l}\text { Geobacillus } \\
\text { kaustophilus DSM } \\
7263^{T}\end{array}$ & $50^{\circ} \mathrm{C}$ & 8.0 & short chain fatty acid (C4) & $\mathrm{Ca}^{2+}$ & $\begin{array}{l}\mathrm{Mg}^{2+}{ }^{2} \mathrm{Na}^{+}, \mathrm{Zn}^{2+}, \mathrm{PMSF}, \mathrm{DTT}, \beta-\mathrm{ME}, \mathrm{SDS}, \\
\mathrm{DMSO}, \text { Ethanol, 2-Propanol }\end{array}$ & Özdemir et al., 2021 \\
\hline
\end{tabular}

but inhibited by ethylene diamine tetraacetic acid (EDTA), dithiothreitol (DTT), beta-mercaptoethanol ( $\beta$-ME) and sodium dodecyl sulfate (SDS; Yang et al., 2016). Both sodium cholate and iodoacetic acid promote the activity of a lipase derived from $P$. aeruginosa ES3, while phenyl methane sulfonyl fluoride (PMSF) serves as an inhibitor (Sarac et al., 2015). A lipase derived from Janibacter sp. R02, was activated by urea, but inhibited by Triton X-100 and SDS, with 50\% maximum activity observed at an SDS concentration of $0.5 \%(\mathrm{w} / \mathrm{v})$; PMSF had no significant impact on the enzyme activity (Castilla et al., 2016). Finally, a lipase derived from Bacillus halodurans remains relatively stable in commercial detergents and is not affected by EDTA, Triton X100 and Tween 80; however it is activated by para-Chloromethyl benzoic acid (pCMBA) and 5,5'-dithio-bis-[2-nitrobenzoic acid] (DTNB) and inhibited by diethylpyrocarbonate (DEPC), PMSF, 1-ethyl-3-(3-dimethyl aminopropyl) carbodiimide (EDAC)and Woodward's Reagent K (WRK; Dua and Gupta, 2017).

\section{Effects of Organic Solvents on Microbial Lipases}

Lipases can catalyze reactions in aqueous solution and in organic solvents; among the reactions carried out in the latter environment, lipases catalyze transesterification and esterase activity, including ammonolysis, and acidolysis of substrate esters. Various organic solvents have specific effects on lipase activity; similarly, unique organic chemical syntheses require different organic solvents for appropriate product generation. This characteristic of lipase provides a scientific basis for its use in organic chemical synthesis and for biodiesel production.

One lipase derived from Rhizomucor miehei NRRL5282 was found to tolerate organic solvents including low concentrations of methanol, ethanol, propanol, and isopropanol, which had little impact on its enzyme activity (Takó et al., 2017). LipM, a lipase derived from Pseudomonas moraviensis M9, is stable in isopropanol, methanol, and ethanol; however, glycerol, polyethylene glycol (PEG)-400, and PEG-600 all inhibit its activity (Yang et al., 2015a). LipR, a lipase derived from Pseudomonas sp. R0-14, was inhibited slightly by methanol, while glycerol, dimethyl sulfoxide (DMSO), ethanol and PEG600 strongly inhibited its activity (Yang et al., 2015b). LipA, a lipase derived from Pseudomonas protegens pf-5, was inhibited by chloroform but activated by many other organic solvents, including N-hexane, acetone, glycerol, methanol, tert-butanol and ethanol (Zha et al., 2014).

\section{Optimum Substrates for Microbial Lipases}

The substrate specificity of lipase is determined by the structure of the enzyme molecule, especially the structure of the enzyme activity center, the structure of substrate, and factors influencing substrate binding to the active and other factors affecting enzyme activity. As such, various sources of lipases and lipases with variant structures may display unique substrate specificities.

For example, a lipase derived from $T$. lanuginosus, is actually far more reactive with short-chain pNP-esters substrates (Xin et al., 2017). A lipase derived from G. stearothermophilus AH22 has a preference for short-chain methyl ester substrates (i.e., C4; Ekinci et al., 2016). Similarly, a lipase derived from Geobacillus kaustophilus DSM $7263^{T}$ showed maximum activity toward short chain fatty acid (C4), and the enzyme activity was decreased with higher carbon number of fatty acids (Özdemir et al., 2021). However, a lipase from B. ubonensis SL-4 exhibits high catalytic activity against the medium- to long-chain pNP-esters (i.e., C8C16; Yang et al., 2016). A lipase derived from Bacillus sp. displays a moderate preference for triolein (Sivaramakrishnan and Incharoensakdi, 2015), while lipase LipA derived from $P$. protegens pf-5 performs preferential catalysis with medium pNP-esters, as opposed to short- or long-chain pNP-esters (i.e., C8-C10; Zha et al., 2014). A lipase derived from P. pasadenensis displays highest catalytic activity against pNP-esters (C8; Gao et al., 2018), while LipM, a lipase derived from P. moraviensis M9, exhibited high catalytic activity with medium- to long-chain pNP-esters substrates (i.e., C8-C16; Yang et al., 2015a).

\section{THE STRUCTURE AND CATALYTIC MECHANISM OF MICROBIAL LIPASES}

\section{Structure of Lipase From Microorganisms}

Although the molecular weights of microbial lipases can vary from 20 to $60 \mathrm{kDa}$, they are all members of the 


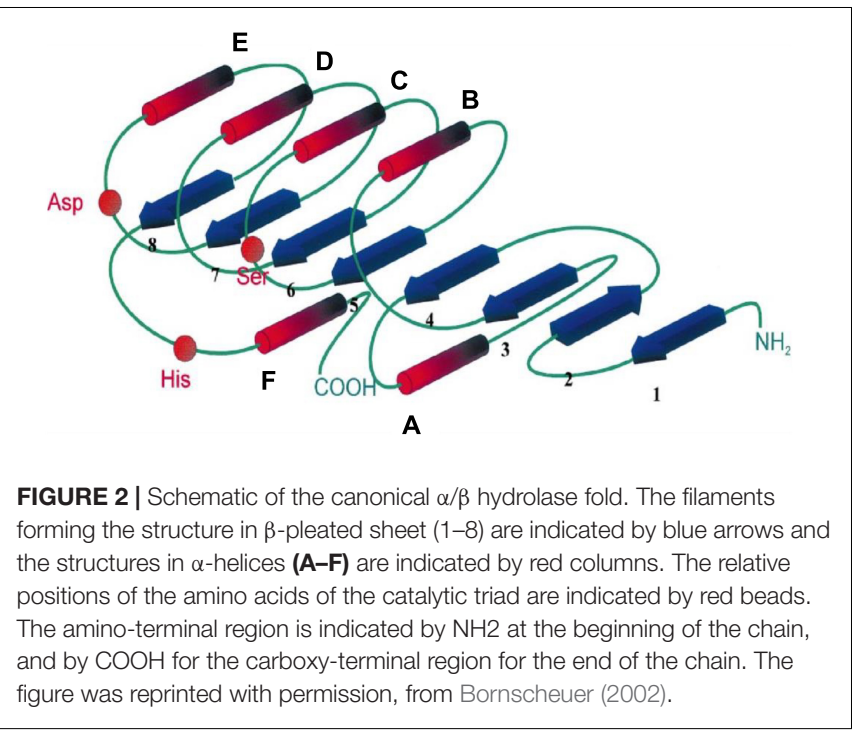

$\alpha / \beta$-hydrolase fold protein family (Nardini and Dijkstra, 1999; Singh and Mukhopadhyay, 2012). Hydrolases are a class of enzymes whose activity depends on the catalytic triad that includes Ser, His and Asp (Farrokh et al., 2014; Faouzi et al., 2015). In the $\alpha / \beta$ hydrolases, these three amino acid residues are detected in order as SerAsp-His; the Ser residues are all located in a conserved catalytic Gly-X-Ser-X-Gly sequence. This conserved pentapeptide sequence is present in all serine hydrolases and plays a key role with respect to the catalytic activity of this group of lipases (Nardini and Dijkstra, 1999; Schreck and Grunden, 2014).

All lipases exhibit similar secondary structure; the main differences observed relate to the number and arrangement of $\alpha$-helices as well as the number and angle of the folds in the $\beta$-strands (Schrag and Cygler, 1997). A typical $\alpha / \beta$ fold is shown in Figure 2.

Most lipases also contain an unstable domain known as a "lid structure" (Sarmah et al., 2018). When at locales other than oil-water interfaces, the lid structure covers the active site; when located at an oil-water interface, the lid will be opened to permit interactions between the catalytic site and the substrate, thereby facilitating solvent catalyzed reaction (Khan et al., 2017; Rrcm et al., 2020). For example, the structure of lipase from $T$. lanuginosus showed different phenomena when close and open. A comparison of both conformations is shown in Figure 3 (Khan et al., 2017). Another important feature of lipases is the "oxygen anion hole." Arpigny and Jaeger divided lipases into three types, GGGX, GX and $\gamma$, according to the preference of "oxygen anion hole" in catalyzing different substrates (Albayati et al., 2020). In addition, there are special interfacial recognition sites in the structure of lipase, which will change the conformation in the presence of lipid and amphiphilic, and the stability of lipase on the interface (Aloulou et al., 2006).

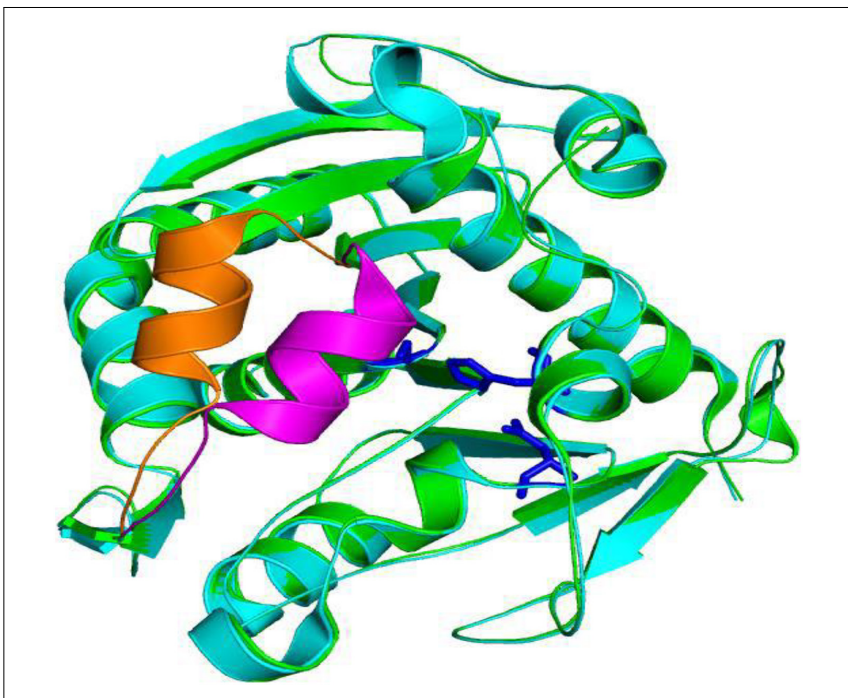

FIGURE 3 | Schematic diagram of superimposition of opening and closing of lipase lid structure of Thermomyces lanuginosus. The close lid, open lid, and catalytic triads were highlighted by magenta, orange, and blue colors, respectively (Khan et al., 2017).

\section{Catalytic Mechanisms of Microbial Lipases}

The catalytic mechanisms associated with microbial lipases rely on a catalytic triad that is very similar to those identified in serine hydrolases (Schreck and Grunden, 2014). The catalytic mechanism of lipase can be divided into four steps, as shown in Figure 4: (a) at the catalytic triad, the histidine residue removes the hydrogen on the serine hydroxyl group, generating a negatively charged oxygen molecule that can undergo nucleophilic interactions with a positively charged carbonyl carbon, resulting in the formation of a covalent bonds, followed by (b) the lipase electrophilic region (i.e., the oxygen anion hole) is formed, followed by a stable enzymesubstrate tetrahedral transition state, followed by (c) the ester bond is then broken, resulting in the release of the fatty-acid alcohol, formation of acyl covalent intermediate complexes, finally (d) the temporary bonds between the serine and the substrate are then broken, resulting in the release the acyl substrate.

\section{HETEROLOGOUS EXPRESSION AND MOLECULAR MODIFICATION OF MICROBIAL LIPASES}

\section{Heterologous Expression of Microbial Lipases}

Heterologous expression is an effective means to promote largescale industrial production of one or more specific lipase. Heterologous expression systems are associated with significant advantages, including the fact it is typically does not require 


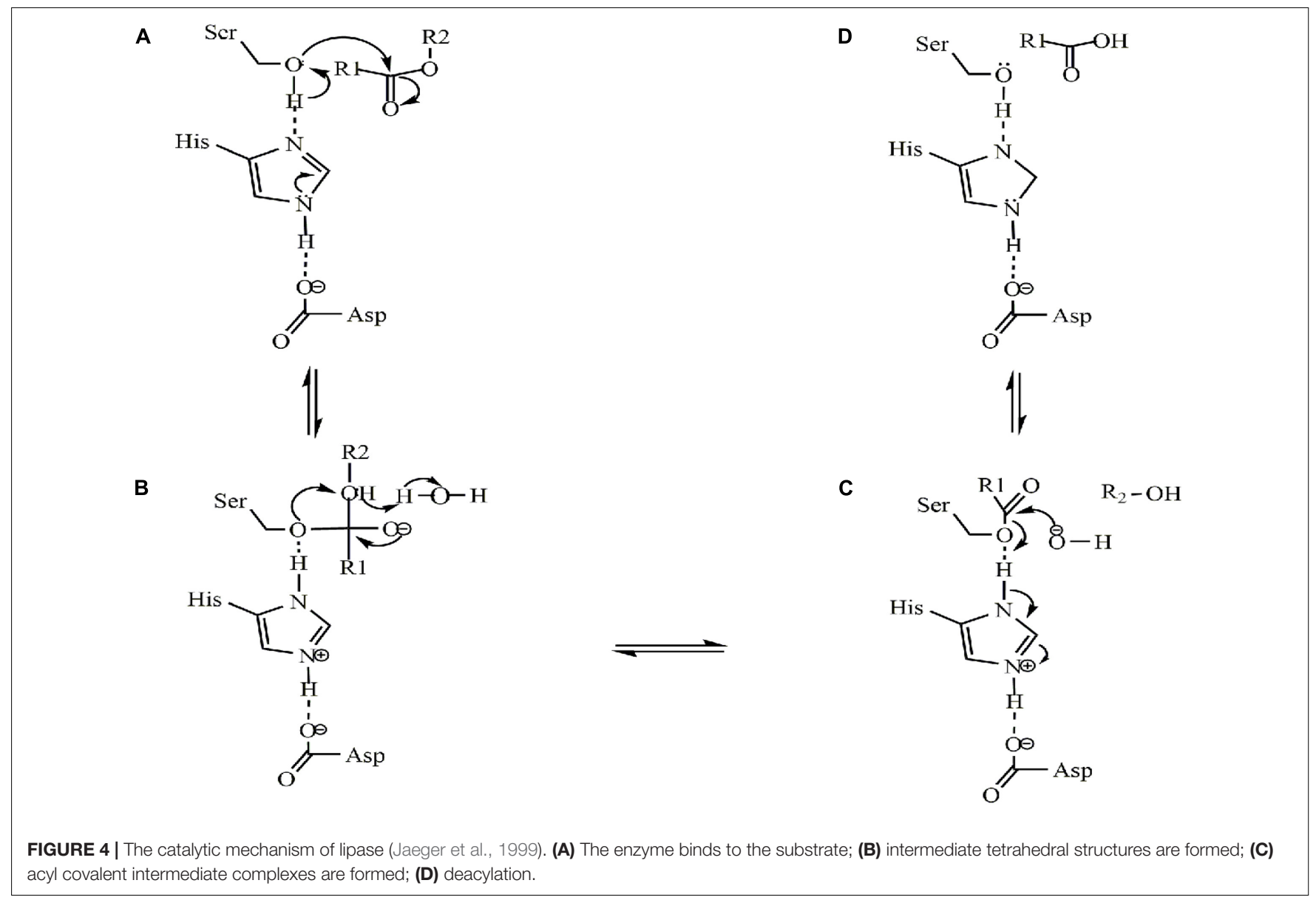

lipids and other inducers to promote biosynthesis; this reduces the overall complexity of the fermentation process. Common methods used to generate recombinant lipase include bacterial, yeast, baculovirus/insect, mammalian, and filamentous fungalbased expression systems; bacterial, yeast and filamentous fungalbased expression systems are among the most widely used (Valero, 2018).

\section{Prokaryotic Expression Systems}

Heterologous expression in Escherichia coli is the most commonly used prokaryotic expression system; this has been facilitated by a deep understanding of the bacterial genome, genetics, physiology, and mechanisms underlying gene expression. E. coli grow rapidly in culture and can achieve high-density growth in a short period of time using inexpensive media that is suitable for continuous fermentation. The yield of recombinant protein per unit volume tends to be relatively high, and can represent up to $30 \%$ of the secreted protein. Recombinant lipase expressed in E. coli can be located in the cytoplasm or secreted to the extracellular environment; it can exist in the form of inclusion bodies or expressed as a fusion protein with a FLAG epitope tag or fluorescent protein in order to avoid intracellular degradation and to simplify the subsequent separation and purification processes (Yin et al., 2007).
However, heterologous expression in E. coli is associated with the following disadvantages: (1) when eukaryotic proteins, especially heterologous proteins containing disulfide bonds, are expressed in E. coli, inactive cytoplasmic inclusion bodies can be formed due to improper protein folding; (2) Heterologous proteins that are not secreted often do not undergo proper folding and post-translational modification; this can lead to inactivation and degradation of heterologous proteins by the host; (3) the recombinant protein of interest needs to be separated from many background E. coli proteins, resulting in the need for complex separation and purification steps; (4) the E. coli expression systems involves contamination with lipopolysaccharide (LPS) which is a proinflammatory molecule in mammalian hosts that plays a key role in host-pathogen interaction with the innate immune system. Other commonly used prokaryotic expression systems include those based in B. subtilis, Ralstonia eutropha, and Pseudomonas spp. Compared with the E. coli expression system, the $B$. subtilis system facilitates recombinant protein secretion, and has no Gram-negative lipopolysaccharide components; as such, this system is suitable for large-scale highdensity fermentation. However, the instability of the bacterial host protease system and associated plasmid loss can result in a decrease in recombinant lipase production. Less is known regarding the expression of recombinant lipases in systems based on Ralstonia eutropha or Pseudomonas (Valero, 2018). 


\section{Yeast Expression Systems}

Similar to bacteria, yeast grow rapidly in culture and are relative simple to use; however, yeast cells promote more complete posttranslational modifications that serve to maintain recombinant proteins in native, active state (Madzak et al., 2004). As such, yeast expression systems are used widely in industry, scientific research, and pharmaceutical fields. Common yeast expression systems include those featuring $S$. cerevisiae, P. pastoris, Hansenula, Yarrowia lipolytica, C. boidinii expression system, and Kluyveromyces lactis.

As a Generally Recognized As Safe microorganism, the genetic background of S. cerevisiae has been fully clarified; it is the first eukaryotic organism to be used to promote recombinant gene expression (Boer et al., 2007). However, the expression system of $S$. cerevisiae includes a number of disadvantages, including poor plasmid stability and relatively weak levels of protein secretion; as such, the expression levels of most recombinant proteins are not high. Furthermore, amplification of fermentation process is not straightforward, and there are also problems associated with protein over-glycosylation (Valero, 2018).

By contrast, the $P$. pastoris expression system has the advantage of simplicity, rapid growth rate, and relatively low nutritional requirements. Rather than the aforementioned plasmid-based expression systems, the exogenous genes are integrated into host chromosomes via homologous recombination (Wang et al., 2019), which provides the advantage of genetic stability. Furthermore, exogenous gene expression is strictly regulated under the control of the alcohol oxidase (AOX) promoter in yeast cells. Moreover, compared with the results form prokaryotic expression systems, yeast expression systems produce large amounts of protein that can be released into the extracellular milieu, which facilitates their ultimate separation and purification. Finally, processing mechanisms in yeast cells promote appropriate post-translational modification of recombinant proteins; as such, it is usually easier to generate recombinant proteins with full biological activity.

Expression systems featuring Yarrowia and Hansenula are also commonly used for recombinant lipase expression; Yarrowia have been used to promote overexpression of their own lipase (Janek et al., 2020).

\section{Filamentous Fungal-Based Expression Systems}

The genetic and physiological backgrounds of the filamentous fungi are less well understood than are those used for expression of recombinant proteins in prokaryotic cells and yeast. However, they are clearly multifunctional, and as such, they are in wide used as recombinant expression systems. Filamentous fungi can generally utilize inexpensive raw materials to support growth and to promote efficient expression and secretion of recombinant proteins in a manner that is suitable for large-scale industrial production. The post-translational modification processes within these cells are similar to those of eukaryotes and serve to ensure biological activity of recombinant proteins produced (Su et al., 2011).

\section{Molecular Modification of Microbial Lipases}

Currently, there are only a limited number of microbial lipases that are in use for industrial applications. One of the important means that might be used to broaden the research field and to obtain enzyme preparations with improved physical, chemical, and catalytic properties would be via molecular modification of existing lipases by genetic engineering. The molecular modification strategies used to alter the properties of enzymes have been divided into three categories, including rational design, irrational design and semi-rational design (Rrcm et al., 2020). Appropriate use of rational design strategies presupposes a clear understanding of the three-dimensional structure of the enzyme. In combination with bioinformatics, a large number of simulated docking sites can be selected for modification during the early stages of this procedure. Generally, changes in the protein sequence are introduced via site-directed mutagenesis techniques. By contrast, irrational design does not require any specific understanding of enzyme structure. Introduction of mutations is largely random, as such, this approach is typically combined with high-throughput screening, which can be both time and resource- consuming. Semi-rational design is a combination of these two approaches; this approach typically includes homologous modeling or other means to generate a basic understanding of protein structure to facilitate a semirational mutagenesis strategy.

\section{Irrational Design}

Irrational design is also known as directed evolution. In this design process, protein structural and functional information is not needed (Ollis et al., 2016); random mutations are introduced into the target gene via a means that is meant to simulate natural evolution; targeted screening is then conducted so as to identify the protein that meets the specific structural or functional requirements (Albayati et al., 2020). Generally, this process involves two steps, including first, the construction of the mutant library, which needs to be of adequate size and diversity; the second step involves high-throughput screening, which is fast, sensitive, and directional. Druteika et al. used this technique to mutate Geobacillus lipase GD-95 from with the goal of improving enzyme activity; it was identified that the specific activity of GD-95RM lipase increased by 1.3 times $(2000 \mathrm{U} / \mathrm{mg}$; Druteika et al., 2020).

\section{Rational Design}

The use of a rational design protocol presupposes a knowledge of the three-dimensional structure and function of the protein to be targeted; using this methods, specific changes are introduced based on the understanding of the structurefunction relationship. In order to improve the thermostability of r27RCL from Rhizopus chinensis, Wang Rui et al. screened four thermostable variants S142A, D217V, Q239F, and S250Y by reasonable design, and then combined together to generate a quadruple-mutation (S142A/D217V/Q239F/S250Y) variant, called $\mathrm{m} 31 . \mathrm{m} 31$ showed enhanced thermal stability, and its half-life was prolonged by 41.7 times at $60^{\circ} \mathrm{C}$ (Wang et al., 2020). 


\section{Semi-Rational Design}

Semi-rational design is a combination of rational design and directed evolution. When designing changes to the DNA sequence based on this technology, some information related to protein structure and function is required. Mutations are introduced to alter the coding sequence at specific points; random and site-specific saturation mutations are carried out simultaneously. Random mutation and screening, followed by site-specific saturation mutation, can be subjected to a scaled-down selection process, according to the needs of the experimental design (Liu et al., 2011). For example, Jiang Hong et al. in order to enhancement of hydrogen peroxide tolerance of lipase LipA from B. subtilis, Constructed and screened a minimal Library of $B$. subtilis lipase LiPA composed of 26 mutants based on the known 3D structure information and mass spectrometric analysis. In the mutation library, the $\mathrm{C}_{50}$ value and $t_{1 / 2}$ value of the best mutant variant, LipA$\mathrm{Trp}^{42} \mathrm{Ala} / \mathrm{Met}^{134} \mathrm{Glu}$ was increased by 9.1 -fold and 9.5 -fold, respectively (Jiang et al., 2020).

With the development of molecular biology technology, heterologous expression and molecular modification have been widely used in the expression of microbial lipase. Heterologous high efficiency expression of enzyme gene or molecular modification of lipase protein to improve the corresponding enzymatic properties is the most direct and convenient way to obtain a highly active enzyme or improve the corresponding enzymatic properties. In view of the low efficiency of lipase heterologous expression and the need to improve the fermentation level, the appropriate heterologous expression system was selected. Based on heterologous expression systems and to express lipase fitment problem, can use bioinformatics, synthetic biology, systems biology, such as thoughts and technical means, through the prediction and design effective reform way, reconstruct metabolic network, optimize the integration of different fine properties such as strategy, build efficient expression of heterologous lipase system, By optimizing the key technological factors and process regulation in the lipase production process, the optimal control technology of the lipase production process was determined, and the stable and efficient production of exogenous lipase was realized, so that the lipase was developed satisfactorily in industry.

\section{Applications of Microbial Lipases}

Microbial lipase is currently in prominent use in numerous biotechnology and industry applications; the market for these enzymes is expected to expand further over the next 5 years. A great deal of time and effort has been devoted to the development of new technologies that will ultimately serve to increase the utility and application of lipases in a variety of important fields. Among the current industrial applications, microbial lipases are used widely for the production of food, medicine, detergents, paper, biodiesel fuel, textiles, and cosmetics (Newswire, 2018). Major industrial applications of lipases are summarized in Table 2.

\section{Applications of Microbial Lipases in the Food Industry}

Traditional processes generally use inorganic acids or metal oxidation to catalyze the hydrolysis or esterification of oil; the reaction conditions are especially harsh, requiring special equipment to carry out the reaction. Furthermore, the reaction cycle is long and involves significant energy consumption, high costs, and the chance of environmental pollution. By contrast, the use of lipase as a biocatalyst can overcome these problems; lipase-mediated reactions are specific and highly efficient. As such, lipase-catalyzed reactions are gradually replacing the traditional methods.

Lipase can also be used to refine oil and by removing free fatty acids; this method may also be used to modify lowerquality oils to obtain a high value-added product (Konkit and Kim, 2016). Lipase can also be used to improve food flavor. In the dairy industry, lipase hydrolyzes milk fat; this could greatly improve the flavor and taste of dairy products and increase their nutritional value (Konkit and Kim, 2016). A lipase purified from Lactobacillus plantarum has been used in the synthesis of fermented cheese-based foods (Esteban-Torres et al., 2015). Lipase can also be used to improve the quality of baked goods; it can whiten darker breads, improve the taste and quality of baked foods, and extend their shelf life (Lamsal and Faubion, 2009). Lipase is also commonly used in alcoholic beverage processing to improve flavor and increase product attractiveness (Chandra et al., 2020). Immobilized lipase from Aspergillus $s p$. (Resinase A 2X) may also contribute to the synthesis of perfume; it uses a harmless solvent and the product recovery is simple (Gricajeva et al., 2018). A lipase purified immobilized lipase isolated from $R$. miehei (immobilized on anionic exchange support) have been used as pentyl nonanoate in enhancing fruit aroma (Muniandy et al., 2019).

\section{Medical Applications of Microbial Lipases}

Lipase is a basic enzyme that contributes to the metabolism of fat; it is an important drug target, a biomarker, and has been used to produce drug intermediates such as unsaturated fatty acids. Lipase expression can be regulated to aid in digestion; it has also been used as part of a strategy to treat malignant tumors (Bancerz, 2017).

Lipase can also contribute to the process of chiral drug resolution; selective esterification facilitates separation of the racemic mixture and isolation of a single active enantiomer (Kumar et al., 2017). Dai and Xia (2005) found that the enantioselectivity of lipase was greater than 100 when using Penicillium extendus to split the intermediate.-fold. The separation of ibuprofen isomers features the advantages of this technology. Rhodothermus marinus DSM 4252 lipase degraded ibuprofen ester in immobilized form to output (S)-enantiopure ibuprofen (Memarpoor-Yazdi et al., 2018).

Lipase-based sensors are used as diagnostic tools to detect triglyceride, cholesterol and phospholipid levels in patient blood samples (Herrera-Lopez, 2012). Similarly, lipase obtained from staphylococcal strains has been used in the manufacture of antioxidants such as ethanol-acetate and eugenyl benzoate (Horchani et al., 2012). 
TABLE 2 | Industrial applications of microbial lipases.

\begin{tabular}{|c|c|c|c|}
\hline Industry & Action & Product or application & References \\
\hline Fats and oils & Transesterification; hydrolysis & $\begin{array}{l}\text { Cocoa butter, margarine, fatty acids, } \\
\text { glycerol, mono-, and diglycerides }\end{array}$ & Konkit and Kim, 2016 \\
\hline Dairy foods & $\begin{array}{l}\text { Hydrolysis of milk fat, cheese } \\
\text { ripening, modification of butter fat }\end{array}$ & $\begin{array}{l}\text { Development of flavoring agents in milk, } \\
\text { cheese, and butter }\end{array}$ & Esteban-Torres et al., 2015; Konkit and Kim, 2016 \\
\hline Bakery foods & Flavor improvement & Shelf-life prolongation & Lamsal and Faubion, 2009 \\
\hline Beverages & Improved aroma & Beverages & Chandra et al., 2020 \\
\hline Food dressings & Quality improvement & Spices and seasonings & Gricajeva et al., 2018 \\
\hline $\begin{array}{l}\text { Pharmaceuticals and } \\
\text { Medical equipment }\end{array}$ & Transesterification, hydrolysis & $\begin{array}{l}\text { Treatment of tumors, chiral drug } \\
\text { resolution, antioxidants, digestive aids } \\
\text { and Blood sensor }\end{array}$ & $\begin{array}{l}\text { Dai and Xia, 2005; Herrera-Lopez, 2012; Horchani et al., 2012; } \\
\text { Bancerz, 2017; Kumar et al., 2017; Memarpoor-Yazdi et al., } 2018\end{array}$ \\
\hline Pulp and paper & Hydrolysis & Paper with improved quality & $\begin{array}{l}\text { Demuner et al., 2011; Horchani et al., 2012; Liu et al., 2012; } \\
\text { Almeida et al., 2018; Patel et al., } 2019\end{array}$ \\
\hline Washing & Hydrolysis & Removal of fats & $\begin{array}{l}\text { Niyonzima and More, 2015; Phuah et al., 2015; Kumar et al., 2016; } \\
\text { Unni et al., 2016; Holland and Sajic, 2017; Mehta et al., 2017; } \\
\text { Saraswat et al., 2017; Abol-Fotouh et al., } 2021\end{array}$ \\
\hline Biodiesel & $\begin{array}{l}\text { Transesterification, hydrolysis, } \\
\text { synthesis }\end{array}$ & Biodiesel production & $\begin{array}{l}\text { Karmee et al., 2015; Tran et al., 2016; Khosla et al., 2017; Tian } \\
\text { et al., 2017; Li et al., 2020; Sorte et al., 2020; Talavari et al., } 2020\end{array}$ \\
\hline Leather & Hydrolysis & Leather products & Kavitha et al., 2018; Rashid et al., 2018 \\
\hline Cosmetics & Synthesis & Emulsifiers, moisturizers & $\begin{array}{l}\text { Gupta et al., 2015; Kim et al., 2015; Ugo et al., 2017; Uppada } \\
\text { et al., 2017; Tufiño et al., } 2019\end{array}$ \\
\hline Environmental protection & Transesterification, hydrolysis & Environmental detection and repair & $\begin{array}{l}\text { Lauprasert et al., 2017; Bucur et al., 2018; Hassan et al., 2018; Ma } \\
\text { et al., 2018; Kumar et al., } 2020\end{array}$ \\
\hline
\end{tabular}

\section{Application of Microbial Lipase in the Pulp and Paper Industry}

Resin is often detected in pulp and paper processing; this may be the result of raw material in the storage tank, resin deposition on the paper stock, and oils from the roller resin binder; this can result paper destruction, downtime, and unstable operation. Resins and oils also present obstacles with respect to machine cleaning and maintenance, and typically result in great inconvenience. Resin deposition will also reduce the efficiency of washing, screening, and purification of pulp. Lipase could be used to remove esters from pulp, thus improving the quality and production capacity (Horchani et al., 2012).

In the papermaking industry, the addition of lipase can remove only the contaminating resins and oils in the paper; this will serve to reduce the breakage and to ensure the paper quality and output (Almeida et al., 2018).

Lipase can also treat anion residue and bitumen deposition in papermaking so as to avoid negative effects on the operation of papermaking equipment (Demuner et al., 2011; Liu et al., 2012). Nippon, one of Japan's major paper industries, has developed a method to control contamination from wood pitch by effecting their hydrolysis (90\%) using C. rugosa fungal lipase (Patel et al., 2019).

\section{Applications of Microbial Lipase in the Detergent Industry}

One of the most important commercial applications of lipase is as a detergent additive. Lipases are the second most significant detergent additive after proteases; this accounts for $32 \%$ of total lipase sales. According to estimation, one thousand tons of lipases in almost thirteen billion tons of detergent are added every year (Mehta et al., 2017). Lipase added to the detergent can increase the flexibility of the fabric and can enhance decontamination without adding pollution to the environment (Kumar et al., 2016). Lipases added to detergent must be capable of functioning in a strong alkaline environment, at high temperature, and with various surfactants that are typically used in routine detergent preparations.

The lipase source strains commonly used in the detergent industry include those from B. licheniformis, Geobacillus spp., Serratia marcescens DEPTK21, B. flexus XJU-1, Bacillus pumilus SG2 (Niyonzima and More, 2015), Staphylococcus arlettae, Bacillus cepacia, Pseudomonas fluorescens and Candida spp. (Phuah et al., 2015; Su et al., 2015). There are also some publications reporting that lipase derived from A. niger performs well in normal temperature washes and is suitable for use as a detergent additive (Unni et al., 2016). A lipase from B. subtilis was resistant to surfactants, oxidizing agents and commercial detergents, suggesting it as a potential candidate for detergent formulation (Saraswat et al., 2017). Others found that G. stearothermophilus FMR12 showed high lipolytic activity at $70^{\circ} \mathrm{C}$ in $\mathrm{pH} 9$ and has been successfully utilized as detergents (Abol-Fotouh et al., 2021). In 2017, a patent was registered for the use of lipase in washing powder to be used for cold water cleaning (Holland and Sajic, 2017).

\section{Applications of Microbial Lipases in Biodiesel Production}

Biofuels, including biodiesel, have become a renewable alternative to fossil fuels (Shuba and Kifle, 2018; Bilal et al., 
2021). The production of biodiesel typically relies on animal fat and vegetable oil as biomass; as such, biodiesel a modern source of clean energy (Filho et al., 2019). Biodiesel is comprised of a fatty-acid monoester that is generated by transesterification of triglycerides from fats (Filho et al., 2019). At present, biodiesel is produced mainly by alkaline catalysis and supercritical fluid catalysis (Mandolesi De Araújo et al., 2013); lipase catalysis has been used in the industrial production of biodiesel (Li et al., 2020; Puna et al., 2020; Talavari et al., 2020). According to the research of Tran et al. (2016) the biodiesel conversion rate using sunflower oil in a packed bed reactor with immobilized Burkholderia lipase, they found that a single packed bed reactor resulted in a $67 \%$ biodiesel conversion rate. However, when the reaction was carried out in a continuous packed bed reactor, the biodiesel conversion rate was increased to $85 \%$ (Tran et al., 2016).

Methanol and edible waste oil were also converted into biodiesel and glycerin via the actions of microbial lipase (Karmee et al., 2015). Such as, T. lanuginosus lipase form catalyzed methanolysis of waste oil for the production of biodiesel (Tian et al., 2017). Using the commercial lipase Novozyme ${ }^{\circledR}$ 435 (Made by Novozymes), edible waste oil was used as raw material to produce biodiesel via enzyme-catalyzed regeneration (Sorte et al., 2020). Similarly, Khosla et al. (2017) isolated an extracellular lipase from Pseudomonas ISTPL3; lipid production of liposophore ISTD04 was used for transesterification to produce biodiesel fuel (Khosla et al., 2017).

\section{Other Applications of Microbial Lipases}

Microbial lipases have been used as environmentally friendly degreasers in the leather processing industry; lipases were used to replace surfactants in cowhide degreasing. For sheepskin, which contains up to $40 \%$ fat, solvents are often used; these can also be replaced by lipases and surfactants (Kavitha et al., 2018). For example, an in-house extracted and purified lipase from Aspergillus cervinus was immobilized onto chitosan-alginate (CTS-ALG) beads for sheep skin depilation (Rashid et al., 2018).

Lipases also have the capacity to produce fragrance and thus may be used for the production of cosmetics and perfumes (Gupta et al., 2015; Kim et al., 2015; Ugo et al., 2017; Uppada et al., 2017; Tufiño et al., 2019). Lipase has also been used as a major ingredient in topical creams and in oral medications to aid weight loss through removal fat (Sonne et al., 2015); lipase is also in wide use for the production of curls (Shafqat et al., 2015).

Lipases can be used to detect environmental pollutants, such as pesticides (Bucur et al., 2018; Ma et al., 2018); they have been used frequently for environmental remediation (Kumar et al., 2020). The use of lipase to treat industrial, edible waste oil, and waste water can reduce environmental pollution (Lauprasert et al., 2017; Hassan et al., 2018; Kumar et al., 2020).

\section{CONCLUSION AND FUTURE PERSPECTIVES}

Our analysis of the existing literature revealed that microbial lipases are among the most versatile and productive lipases in current use. Microbial lipases function over a wide temperature and $\mathrm{pH}$ range, exhibit a remarkable range of substrate diversity and enantioselectivity, and are the first choice for the generation of current and future biocatalysts. Heterologous expression and molecular modification strategies have led to the large-scale application of lipase in industrial production; this has created an important role for microbial lipases in food, pharmaceutical, papermaking, detergent, and biodiesel production, among other fields. Although several microbial strains with lipases capable of functioning at both low and high temperatures have been identified, and efforts have been made toward engineering lipases that exhibit these critical characteristics, issues regarding high production cost and insufficient lipase specificity need to be overcome.

With the increasing application of lipase industrialization, demand for this reagent in the both the papermaking and chemical industries are increasing each day. As such, scientific research in this field is currently focused on ways to identify and to generate new lipases, to expand the search range via the use of bioinformatics, and to employ a wide range of genetic tools and calculations for screening and construction. Among the targets to consider, it would be helpful find ways to improve the properties of existing microbial lipases, including the means to increase activity, productivity, thermal stability, specificity, and antipodal selectivity, as well as to reduce production costs. In addition, methods to improve expansion and optimization of large-scale culture are required; this process requires substantial attention to ensure the economic feasibility of lipase catalytic process. Further research focused on the biochemistry, enzymology, and applications of lipase will play an important role in promoting its future commercial feasibility.

\section{AUTHOR CONTRIBUTIONS}

TW and KL conceived the study. WY, KL, HL, and YJ wrote the draft of the manuscript. WW and RW critically reviewed the full manuscript content. All authors read and approved the final manuscript.

\section{FUNDING}

This work was supported by the National Key Research and Development Program of China (No. 2019YFC1905900); National Natural Science Foundation of China (No. 32001632); Focus on Research and Development Plan in Shandong Province (Nos. 2019JZZY011003 and 2020CXGC010603); Young doctorate Cooperation Fund Project, QiLu University of Technology (Shandong Academy of Sciences; BSHZ20180016); Natural Science Foundation of Shandong Province (ZR2019PC060); Shandong Province Higher Educational Science and Technology Program (A18KA116); Open Foundation of State Key Laboratory of Biobased Material and Green Papermaking, Qilu University of Technology, Shandong Academy of Sciences (No. KF201822); The Foundation of Cultivating Subject for Biology and Biochemistry, Qilu University of Technology (No. 202008); and Taishan Industry Leading Talent (scy20180103 to RW). 


\section{REFERENCES}

Abol-Fotouh, D., Alhagar, O. E. A., and Hassan, M. A. (2021). Optimization, purification, and biochemical characterization of thermoalkaliphilic lipase from a novel Geobacillus stearothermophilus FMR12 for detergent formulations. Int. J. Biol. Macromol. 181, 125-135. doi: 10.1016/j.ijbiomac.2021.03.111

Adina, S. R., Suwanto, A., Meryandini, A., and Puspitasari, E. (2021). Expression of novel acidic lipase from Micrococcus luteus in Pichia pastoris and its application in transesterification. J. Genet. Eng. Biotechnol. 19:55.

Albayati, S. H., Masomian, M., Ishak, S., Ali, M., and Rahman, R. (2020). Main structural targets for engineering lipase substrate specificity. Catalysts 10:747. doi: $10.3390 /$ catal 10070747

Almeida, A. F. D., Terrasan, C. R. F., Terrone, C. C., Tauk-Tornisielo, S. M., and Carmona, E. C. (2018). Biochemical properties of free and immobilized Candida viswanathii lipase on octyl-agarose support: hydrolysis of triacylglycerol and soy lecithin. Process Biochem. 65, 71-80. doi: 10.1016/j. procbio.2017.10.019

Almeida, J. M., Alnoch, R. C., Souza, E. M., Mitchell, D. A., and Krieger, N. (2020). Metagenomics: is it a powerful tool to obtain lipases for application in biocatalysis? Biochim. Biophys. Acta Proteins Proteom. 1868:140320. doi: 10.1016/j.bbapap.2019.140320

Aloulou, A., Rodriguez, J. A., Fernandez, S., Van Oosterhout, D., Puccinelli, D., and Carriere, F. (2006). Exploring the specific features of interfacial enzymology based on lipase studies. Biochim. Biophys. Acta 1761, 995-1013. doi: 10.1016/j. bbalip.2006.06.009

Asmat, S., Husain, Q., and Khan, M. S. (2018). A polypyrrole-methyl anthranilate functionalized worm-like titanium dioxide nanocomposite as an innovative tool for immobilization of lipase: preparation, activity, stability and molecular docking investigations. N. J. Chem. 42, 91-102.

Avhad, M. R., and Marchetti, J. M. (2019). "Chapter 7 - uses of enzymes for biodiesel production," in Advanced Bioprocessing for Alternative Fuels, Biobased Chemicals, and Bioproducts, ed. M. Hosseini (Sawston: Woodhead Publishing), 135-152. doi: 10.1016/b978-0-12-817941-3.00007-3

Bancerz, R. (2017). Industrial application of lipases. Postepy Biochem. 63, 335-341.

Bezzine, S., Carrière, F., De Caro, J., Verger, R., and De Caro, A. (1998). Human pancreatic lipase: an exposed hydrophobic loop from the C-terminal domain may contribute to interfacial binding. Biochemistry 37, 11846-11855. doi: 10 . 1021/bi973136r

Bharathi, D., and Rajalakshmi, G. (2019). Microbial lipases: an overview of screening, production and purification. Biocatal. Agric. Biotechnol. 22:101368. doi: 10.1016/j.bcab.2019.101368

Bilal, M., Fernandes, C. D., Mehmood, T., Nadeem, F., Tabassam, Q., and Ferreira, L. F. R. (2021). Immobilized lipases-based nano-biocatalytic systems - A versatile platform with incredible biotechnological potential. Int. J. Biol. Macromol. 175, 108-122. doi: 10.1016/j.ijbiomac.2021.02.010

Boer, E., Steinborn, G., Kunze, G., and Gellissen, G. (2007). Yeast expression platforms. Appl. Microbiol. Biotechnol. 77, 513-523. doi: 10.1007/s00253-0071209-0

Bornscheuer, U. T. (2002). Microbial carboxyl esterases: classification, properties and application in biocatalysis. FEMS Microbiol. Rev. 26, 73-81. doi: 10.1111/j. 1574-6976.2002.tb00599.x

Borowiecki, P., Justyniak, I., and Ochal, Z. (2017). Lipase-catalyzed kinetic resolution approach toward enantiomerically enriched 1-( $\beta$ hydroxypropyl)indoles. Tetrahedron 28, 1717-1732. doi: 10.1016/j.tetasy. 2017.10.010

Bucur, B., Munteanu, F. D., Marty, J. L., and Vasilescu, A. (2018). Advances in enzyme-based biosensors for pesticide detection. Biosensors (Basel) 8:27. doi: 10.3390/bios8020027

Castilla, A., Panizza, P., Rodríguez, D., Bonino, L., Díaz, P., Irazoqui, G., et al. (2016). A novel thermophilic and halophilic esterase from Janibacter sp. R02, the first member of a new lipase family (Family XVII). Enzyme Microbial. Technol. 98:86.

Cen, Y., Singh, W., Arkin, M., Moody, T. S., Huang, M., Zhou, J., et al. (2019). Artificial cysteine-lipases with high activity and altered catalytic mechanism created by laboratory evolution. Nat. Commun. 10:3198.

Chandra, P., Enespa, Singh, R., and Arora, P. K. (2020). Microbial lipases and their industrial applications: a comprehensive review. Microb. Cell Fact 19:169.
Dai, D., and Xia, L. (2005). Enhanced production of Penicillium expansum PED03 lipase through control of culture conditions and application of the crude enzyme in kinetic resolution of racemic Allethrolone. Biotechnol. Prog. 21, 1165-1168. doi: 10.1021/bp0500563

Dati, F., and Grenner, G. (1984). A new approach to the diagnosis of pancreatic diseases by immunochemical lipase quantitation. Ric. Clin. Lab. 14, 399-407.

Demuner, B. J., Junior, N. P., and Antunes, A. (2011). Technology prospecting on enzymes for the pulp and paper industry. J. Technol. Manag. Innov. 6, 148-158. doi: $10.4067 / \mathrm{s} 0718-27242011000300011$

Dharmsthiti, S., Pratuangdejkul, J., Theeragool, G. T., and Luchai, S. (1998). Lipase activity and gene cloning of Acinetobacter calcoaceticus LP009. J. Gen. Appl. Microbiol. 44, 139-145. doi: 10.2323/jgam.44.139

Druteika, G., Sadauskas, M., Malunavicius, V., Lastauskiene, E., and Gudiukaite, R. (2020). New engineered Geobacillus lipase GD-95RM for industry focusing on the cleaner production of fatty esters and household washing product formulations. World J. Microbiol. Biotechnol. 36:41.

Dua, A., and Gupta, R. (2017). Functional characterization of hormone sensitivelike lipase from Bacillus halodurans: synthesis and recovery of pNP-laurate with high yields. Extremophiles 21, 871-889. doi: 10.1007/s00792-017-0949-8

Dumorne, K., Cordova, D. C., Astorga-Elo, M., and Renganathan, P. (2017). Extremozymes: a potential source for industrial applications. J. Microbiol. Biotechnol. 27, 649-659. doi: 10.4014/jmb.1611.11006

Ekinci, A. P., Dinçer, B., Baltaş, N., and Adıgüzel, A. (2016). Partial purification and characterization of lipase from Geobacillus stearothermophilus AH22. J. Enzyme Inhib. Med. Chem. 31, 325-331. doi: 10.3109/14756366.2015.1024677

Esteban-Torres, M., Mancheño, J. M., De Las Rivas, B., and Muñoz, R. (2015). Characterization of a halotolerant lipase from the lactic acid bacteria Lactobacillus plantarum useful in food fermentations. LWT Food Sci. Technol. 60, 246-252. doi: 10.1016/j.lwt.2014.05.063

Facin, B. R., Valério, A., Bresolin, D., Centenaro, G., De Oliveira, D., and Oliveira, J. V. (2018). Improving reuse cycles of Thermomyces lanuginosus lipase (NS40116) by immobilization in flexible polyurethane. Biocatal. Biotransformation $36,1-9$.

Faouzi, L., Fatimazahra, E. B., Moulay, S., Adel, S., Wifak, B., Soumya, E., et al. (2015). Higher tolerance of a novel lipase from Aspergillus flavus to the presence of free fatty acids at lipid/water interface. Afr. J. Biochem. Res. 9, 9-17. doi: 10.5897/ajbr2014.0804

Farrokh, P., Yakhchali, B., and Karkhane, A. A. (2014). Cloning and characterization of newly isolated lipase from Enterobacter sp. Bn12. Braz. J. Microbiol. 45, 677-687. doi: 10.1590/s1517-83822014000200042

Ferreira-Dias, S., Sandoval, G., Plou, F., and Valero, F. (2013). The potential use of lipases in the production of fatty acid derivatives for the food and nutraceutical industries. Electron. J. Biotechnol. 16, 1.

Filho, D. G., Silva, A. G., and Guidini, C. Z. (2019). Lipases: sources, immobilization methods, and industrial applications. Appl. Microbiol. Biotechnol. 103, 73997423. doi: 10.1007/s00253-019-10027-6

Gao, J., Ou, X., Xu, P., Zong, M., and Lou, W. (2018). Cloning, overexpression, and characterization of a novel organic solvent-tolerant lipase from Paenibacillus pasadenensis CS0611. Chin. J. Catal. 39, 937-945. doi: 10.1016/s1872-2067(18) 63033-5

Gao, K., Chu, W., Sun, J., and Mao, X. (2020). Identification of an alkaline lipase capable of better enrichment of EPA than DHA due to fatty acids selectivity and regioselectivity. Food Chem. 330:127225. doi: 10.1016/j. foodchem.2020.127225

Gao, K., Wang, X., Jiang, H., Sun, J., and Mao, X. (2021). Identification of a GDSL lipase from Streptomyces bacillaris and its application in the preparation of free astaxanthin. J. Biotechnol. 325, 280-287. doi: 10.1016/j.jbiotec.2020.10.009

Geoffry, K., and Achur, R. N. (2017). A novel halophilic extracellular lipase with both hydrolytic and synthetic activities. Biocatal. Agric. Biotechnol. 12, 125-130. doi: 10.1016/j.bcab.2017.09.012

Goomber, S., Kumar, A., and Kaur, J. (2016). Disruption of N terminus long range non covalent interactions shifted temp.opt $25^{\circ} \mathrm{C}$ to cold: evolution of point mutant Bacillus lipase by error prone PCR. Gnen 576, 237-243. doi: 10.1016/j.gene.2015.10.006

Gricajeva, A., Kazlauskas, S., Kalèdienè, L., and Bendikienè, V. (2018). Analysis of Aspergillus sp. lipase immobilization for the application in organic synthesis. Int. J. Biol. Macromol. 108, 1165-1175. doi: 10.1016/j.ijbiomac.2017.11.010 
Gupta, R., Gupta, N., and Rathi, P. (2004). Bacterial lipases: an overview of production, purification and biochemical properties. Appl. Microbiol. Biotechnol. 64, 763-781. doi: 10.1007/s00253-004-1568-8

Gupta, S., Gupta, C., Garg, A. P., and Prakash, D. (2015). A biotechnological approach to microbial based perfumes and flavours. J. Microbiol. Exp. 2, 11-18.

Han, S. Y., Zhao, S. Q., Liu, X. L., Wang, J. L., and Yang, X. P. (2017). Screening, identification and enzymatic properties of an alkaline lipase producing strain. J. Gansu Agric. Univ. 52, 119-125.

Hassan, S. W. M., Abd El Latif, H. H., and Ali, S. M. (2018). Production of coldactive lipase by free and immobilized marine Bacillus cereus HSS: application in wastewater treatment. Front. Microbiol. 9:2377.

Herrera-Lopez, E. J. (2012). Lipase and phospholipase biosensors: a review. Methods Mol. Biol. 861, 525-543. doi: 10.1007/978-1-61779-600-5_30

Hiol, A., Jonzo, M. D., Druet, D., and Comeau, L. (1999). Production, purification and characterization of an extracellular lipase from Mucor hiemalis $\mathrm{f}$. hiemalis. Enzyme Microbial. Technol. 25, 80-87. doi: 10.1016/s0141-0229(99)00 009-5

Holland, B. B. R., and Sajic, B. (2017). Cold-Water Laundry Detergents. Northfield, IL: STEPAN COMPANY.

Horchani, H., Aissa, I., Ouertani, S., Zarai, Z., Gargouri, Y., and Sayari, A. (2012). Staphylococcal lipases: biotechnological applications. J. Mol. Catal. B Enzymatic 76, 125-132. doi: 10.1016/j.molcatb.2011.11.018

Jaeger, K. E., Dijkstra, B. W., and Reetz, M. T. (1999). Bacterial biocatalysts: molecular biology, three-dimensional structures, and biotechnological applications of lipases. Annu. Rev. Microbiol. 53, 315-351. doi: 10.1146/annurev.micro.53.1.315

Jaeger, K. E., Ransac, S., Dijkstra, B. W., Colson, C., Van Heuvel, M., and Misset, O. (1994). Bacterial lipases. FEMS Microbiol. Rev. 15, 29-63.

Janek, T., Mirończuk, A. M., Rymowicz, W., and Dobrowolski, A. (2020). High-yield expression of extracellular lipase from Yarrowia lipolytica and its interactions with lipopeptide biosurfactants: a biophysical approach. Arch. Biochem. Biophys. 689:108475. doi: 10.1016/j.abb.2020.108475

Jiang, H., Jia, W., Duan, M., Lin, H., Huang, J., Li, X., et al. (2020). Enhancement of hydrogen peroxide tolerance of lipase LipA from Bacillus subtilis using semi-rational design. Biochem. Eng. J. 159:107590. doi: 10.1016/j.bej.2020. 107590

Jiao, Y., Tang, J., Wang, Y., and Koral, T. L. (2018). Radio-frequency applications for food processing and safety. Annu. Rev. Food Sci. Technol. 9:105.

Kapoor, M., and Gupta, M. N. (2012). Lipase promiscuity and its biochemical applications. Process Biochem. 47, 555-569. doi: 10.1016/j.procbio.2012. 01.011

Karmee, S. K., Patria, R. D., and Lin, C. S. (2015). Techno-economic evaluation of biodiesel production from waste cooking oil-a case study of Hong Kong. Int. J. Mol. Sci. 16, 4362-4371. doi: 10.3390/ijms16034362

Kavadia, M. R., Yadav, M. G., Odaneth, A. A., and Lali, A. M. (2018). Synthesis of designer triglycerides by enzymatic acidolysis. Biotechnol. Rep. (Amst) 18:e00246. doi: 10.1016/j.btre.2018.e00246

Kavitha, M., Shanthi, C., and Chandrababu, N. K. (2018). Cold active lipase from Pseudomonas sp. VITCLP4 as degreasing agent in leather processing. Indian J. Chem. Technol. 25, 482-488.

Khan, F. I., Lan, D., Durrani, R., Huan, W., Zhao, Z., and Wang, Y. (2017). The lid domain in lipases: structural and functional determinant of enzymatic properties. Front. Bioeng. Biotechnol. 5:16.

Khosla, K., Rathour, R., Maurya, R., Maheshwari, N., Gnansounou, E., Larroche, C., et al. (2017). Biodiesel production from lipid of carbon dioxide sequestrating bacterium and lipase of psychrotolerant Pseudomonas sp. ISTPL3 immobilized on biochar. Bioresour. Technol. 245, 743-750. doi: 10.1016/j.biortech.2017. 08.194

Kim, J. H., Bhatia, S. K., Yoo, D., Seo, H. M., Yi, D. H., Kim, H. J., et al. (2015). Lipase-catalyzed production of 6-O-cinnamoyl-sorbitol from D-sorbitol and cinnamic acid esters. Appl. Biochem. Biotechnol. 176, 244-252. doi: 10.1007/ s12010-015-1570-x

Konkit, M., and Kim, W. (2016). Activities of amylase, proteinase, and lipase enzymes from Lactococcus chungangensis and its application in dairy products. J. Dairy Sci. 99, 4999-5007. doi: 10.3168/jds.2016-11002

Kouker, G., and Jaeger, K. E. (1987). Specific and sensitive plate assay for bacterial lipases. Appl. Environ. Microbiol. 53, 211-213. doi: 10.1128/aem.53.1.211-213. 1987
Ktata, A., Krayem, N., Aloulou, A., Bezzine, S., Sayari, A., Chamkha, M., et al. (2019). Purification, biochemical and molecular study of lipase producing from a newly thermoalkaliphilic Aeribacillus pallidus for oily wastewater treatment. J. Biochem. 167, 89-99. doi: 10.1093/jb/mvz083

Kumar, A., Dhar, K., Kanwar, S. S., and Arora, P. K. (2016). Lipase catalysis in organic solvents: advantages and applications. Biol. Proced Online 18:2.

Kumar, A., Gudiukaite, R., Gricajeva, A., Sadauskas, M., Malunavicius, V., Kamyab, H., et al. (2020). Microbial lipolytic enzymes - promising energy-efficient biocatalysts in bioremediation. Energy 192:116674. doi: 10.1016/j.energy.2019. 116674

Kumar, A., Park, G. D., Patel, S. K. S., Kondaveeti, S., Otari, S., Anwar, M. Z., et al. (2019). SiO2 microparticles with carbon nanotube-derived mesopores as an efficient support for enzyme immobilization. Chem. Eng. J. 359, 1252-1264. doi: 10.1016/j.cej.2018.11.052

Kumar, R., Banoth, L., Banerjee, U. C., and Kaur, J. (2017). Enantiomeric separation of pharmaceutically important drug intermediates using a Metagenomic lipase and optimization of its large scale production. Int. J. Biol. Macromol. 95, 995-1003. doi: 10.1016/j.ijbiomac.2016.10.088

Lamsal, B. P., and Faubion, J. M. (2009). Effect of an enzyme preparation on wheat flour and dough color, mixing, and test baking. LWT Food Sci. Technol. 42, 1461-1467. doi: 10.1016/j.lwt.2009.04.003

Lauprasert, P., Chansirirattana, J., and Paengjan, J. (2017). Effect of selected bacteria as bioremediation on the degradation of fats oils and greases in wastewater from cafeteria grease traps. Eur. J. Sustain. Dev.t 6, 181-186.

Le, L. T. H. L., Yoo, W., Jeon, S., Lee, C., Kim, K. K., Lee, J. H., et al. (2020). Biodiesel and flavor compound production using a novel promiscuous coldadapted SGNH-type lipase (HaSGNH1) from the psychrophilic bacterium Halocynthiibacter arcticus. Biotechnol. Biofuels 13:55.

Li, Q., Chen, Y., Bai, S., Shao, X., Jiang, L., and Li, Q. (2020). Immobilized lipase in bio-based metal-organic frameworks constructed by biomimetic mineralization: a sustainable biocatalyst for biodiesel synthesis. Colloids Surf. B Biointerfaces 188:110812. doi: 10.1016/j.colsurfb.2020.110812

Liu, C., Yang, G., Wu, L., Tian, G., Zhang, Z., and Feng, Y. (2011). Switch of substrate specificity of hyperthermophilic acylaminoacyl peptidase by combination of protein and solvent engineering. Protein Cell 2, 497-506. doi: 10.1007/s13238-011-1057-7

Liu, K., Zhao, G., He, B., Chen, L., and Huang, L. (2012). Immobilization of pectinase and lipase on macroporous resin coated with chitosan for treatment of whitewater from papermaking. Bioresour. Technol. 123, 616-619. doi: 10. 1016/j.biortech.2012.07.074

López-Fernández, J., Barrero, J. J., Benaiges, M., and Valero, F. (2019). Truncated prosequence of Rhizopus oryzae lipase: key factor for production improvement and biocatalyst stability. Catalysts 9:961. doi: 10.3390/catal9110961

Ma, B., Cheong, L.-Z., Weng, X., Tan, C.-P., and Shen, C. (2018). Lipase@ZIF8 nanoparticles-based biosensor for direct and sensitive detection of methyl parathion. Electrochim. Acta 283, 509-516. doi: 10.1016/j.electacta.2018.06.176

Madzak, C., Gaillardin, C., and Beckerich, J.-M. (2004). Heterologous protein expression and secretion in the non-conventional yeast Yarrowia lipolytica: a review. J. Biotechnol. 109, 63-81. doi: 10.1016/j.jbiotec.2003.10.027

Mandolesi De Araújo, C. D., De Andrade, C. C., De Souza, E., Silva, E., and Dupas, F. A. (2013). Biodiesel production from used cooking oil: a review. Renew. Sustain. Energy Rev. 27, 445-452.

Mehta, A., Bodh, U., and Gupta, R. (2017). Fungal lipases: a review. J. Biotech. Res. $8,58-77$.

Memarpoor-Yazdi, M., Karbalaei-Heidari, H. R., and Doroodmand, M. M. (2018). Enantioselective hydrolysis of ibuprofen ethyl ester by a thermophilic immobilized lipase, ELT, from Rhodothermus marinus. Biochem. Eng. J. 130, 55-65. doi: 10.1016/j.bej.2017.11.016

Miyashita, K., Nakajima, K., Fukamachi, I., Muraba, Y., Koga, T., Shimomura, Y., et al. (2017). A new enzyme-linked immunosorbent assay system for human serum hepatic triglyceride lipase. J. Lipid Res. 58, 1591-1597. doi: 10.1194/jlr. $\mathrm{m} 075432$

Momsen, W. E., and Brockman, H. L. (1997). Recovery of monomolecular films in studies of lipolysis. Methods Enzymol. 286, 292-305. doi: 10.1016/s00766879(97)86016-8

Mouad, A. M., Taupin, D., Lehr, L., Yvergnaux, F., and Porto, A. L. M. (2016). Aminolysis of linoleic and salicylic acid derivatives with Candida antarctica lipase B: a solvent-free process to obtain amphiphilic amides for cosmetic 
application. J. Mol. Catal. B Enzymatic 126, 64-68. doi: 10.1016/j.molcatb.2016. 01.002

Muniandy, M., Lasekan, O., Ghazali, H. M., and Rahman, M. (2019). Lipasecatalysed formation of Pentyl Nonanoate using screened immobilized lipase from Rhizomucor meihei. Braz. J. Chem. Eng. 36, 1089-1097. doi: 10.1590/01046632.20190363s20180419

Nardini, M., and Dijkstra, B. W. (1999). Alpha/beta hydrolase fold enzymes: the family keeps growing. Curr. Opin. Struct. Biol. 9, 732-737. doi: 10.1016/s0959440x(99)00037-8

Newswire, P. (2018). Industrial Enzymes Market - Global Industry Analysis, Size, Share, Growth, Trends, and Forecast 2017 - 2025. New York NY: PR Newswire.

Niyonzima, F. N., and More, S. S. (2015). Coproduction of detergent compatible bacterial enzymes and stain removal evaluation. J. Basic Microbiol. 55, 11491158. doi: $10.1002 /$ jobm. 201500112

Ollis, D. L., Porter, J. L., and Rusli, R. A. (2016). Directed evolution of enzymes for industrial biocatalysis. Chembiochem 17, 197-203. doi: 10.1002/cbic.201500280

Özdemir, F. I., Tülek, A., and Erdoğan, D. (2021). Identification and heterologous production of a lipase from Geobacillus kaustophilus DSM 7263T and tailoring Its N-terminal by a His-tag epitope. Protein J. 40, 436-447. doi: 10.1007/ s10930-021-09987-4

Panizza, P., Syfantou, N., Pastor, F. I., Rodriguez, S., and Diaz, P. (2013). Acidic lipase Lip I.3 from a Pseudomonas fluorescens-like strain displays unusual properties and shows activity on secondary alcohols. J. Appl. Microbiol. 114, $722-732$.

Patel, N., Rai, D., Shivam, Shahane, S., and Mishra, U. (2019). Lipases: sources, production, purification, and applications. Recent Pat Biotechnol. 13, 45-56. doi: $10.2174 / 1872208312666181029093333$

Phuah, E.-T., Tang, T.-K., Lee, Y.-Y., Choong, T. S.-Y., Tan, C.-P., and Lai, O.M. (2015). Review on the current state of diacylglycerol production using enzymatic approach. Food Bioprocess Technol. 8, 1169-1186. doi: 10.1007/ s11947-015-1505-0

Priyanka, P., Kinsella, G., Henehan, G. T., and Ryan, B. J. (2019). Isolation, purification and characterization of a novel solvent stable lipase from Pseudomonas reinekei. Protein Expr. Purif. 153, 121-130. doi: 10.1016/j.pep. 2018.08.007

Puna, J. F., Gomes, J. F., and Santos, S. P. (2020). A review on bio-based catalysts (Immobilized Enzymes) used for biodiesel production. Energies 13:3013. doi: 10.3390/en 13113013

Rashid, R., Anwar, Z., Zafar, M., Rashid, T., and Butt, I. (2018). Chitosan-alginate immobilized lipase based catalytic constructs: development, characterization and potential applications. Int. J. Biol. Macromol. 119, 992-1001. doi: 10.1016/ j.ijbiomac.2018.07.192

Rrcm, A., Vo, B., Bm, C., Tndr, A., Jcsds, D., and Ara, E. (2020). Biotechnological relevance of the lipase A from Candida antarctica. Catal. Today 362, 141-154.

Sadaf, A., Grewal, J., Jain, I., Kumari, A., and Khare, S. K. (2018). Stability and structure of Penicillium chrysogenum lipase in the presence of organic solvents. Preparat. Biochem. Biotechnol. 48, 1-6.

Sarac, N., Ugur, A., Boran, R., and Elgin, E. S. (2015). The use of boron compounds for stabilization of lipase from Pseudomonas aeruginosa ES3 for the detergent industry. J. Surf. Detergents 18, 275-285. doi: 10.1007/s11743-0141653-7

Saraswat, R., Verma, V., Sistla, S., and Bhushan, I. (2017). Evaluation of alkali and thermotolerant lipase from an indigenous isolated Bacillus strain for detergent formulation. Electron. J. Biotechnol. 30, 33-38. doi: 10.1016/j.ejbt.2017.08.007

Sarmah, N., Revathi, D., Sheelu, G., Yamuna Rani, K., Sridhar, S., Mehtab, V., et al. (2017). Recent advances on sources and industrial applications of lipases. Biotechnol. Prog. 34, 5-28.

Sarmah, N., Revathi, D., Sheelu, G., Yamuna Rani, K., Sridhar, S., Mehtab, V., et al. (2018). Recent advances on sources and industrial applications of lipases. Biotechnol. Prog. 34, 5-28.

Schrag, J. D., and Cygler, M. (1997). Lipases and alpha/beta hydrolase fold. Methods Enzymol. 284, 85-107. doi: 10.1016/s0076-6879(97)84006-2

Schreck, S. D., and Grunden, A. M. (2014). Biotechnological applications of halophilic lipases and thioesterases. Appl. Microbiol. Biotechnol. 98, 1011-1021. doi: 10.1007/s00253-013-5417-5

Shafqat, I., Shahzad, S., and Yasmin, A. (2015). Microbial potential of lipase production from different industrial effluents. J. Appl. Biol. Sci. 9, 15-19.
Shuba, E. S., and Kifle, D. (2018). Microalgae to biofuels: 'Promising' alternative and renewable energy, review. Renew. Sustain. Energy Rev. 81, 743-755. doi: 10.1016/j.rser.2017.08.042

Singh, A. K., and Mukhopadhyay, M. (2012). Overview of fungal lipase: a review. Appl. Biochem. Biotechnol. 166, 486-520.

Sivaramakrishnan, R., and Incharoensakdi, A. (2015). Purification and characterization of solvent tolerant lipase from Bacillus sp. for methyl ester production from algal oil. J. Biosci. Bioeng. 121, 517-522. doi: 10.1016/j.jbiosc.2015.09.005

Sonne, D. P., Vilsboll, T., and Knop, F. K. (2015). Pancreatic amylase and lipase plasma concentrations are unaffected by increments in endogenous GLP-1 levels following liquid meal tests. Diabetes Care 38, e71-e72.

Sorte, S., Ribeiro, J. P., Coutinho, J. A. P., and Nunes, M. I. (2020). Study of fame production from waste cooking oil: operation in batch and continuous regime with regeneration of enzyme catalyst. Energy Rep. 6, 751-756.

Sri Kaja, B., Lumor, S., Besong, S., Taylor, B., and Ozbay, G. (2018). Investigating enzyme activity of immobilized candida rugosa lipase. J. Food Qual. 2018, 1-9. doi: 10.1155/2018/1618085

Su, J., Zhang, F., Sun, W., Karuppiah, V., Zhang, G., Li, Z., et al. (2015). A new alkaline lipase obtained from the metagenome of marine sponge Ircinia sp. World J. Microbiol. Biotechnol. 31, 1093-1102. doi: 10.1007/s11274-015-1859-5

Su, X., Schmitz, G., Zhang, M., Mackie, R. I., and Cann, I. K. O. (2011). Heterologous gene expression in filamentous fungi. Adv. Appl. Microbiol. 7, 283-287. doi: 10.1016/0167-7799(89)90048-6

Takó, M., Kotogán, A., Papp, T., Kadaikunnan, S., and Vágvölgyi, C. (2017). Purification and properties of extracellular lipases with transesterification activity and 1,3-regioselectivity from Rhizomucor miehei and Rhizopus oryzae. J. Microbiol. Biotechnol. 27, 277-288. doi: 10.4014/jmb.1608.0 8005

Talavari, R., Hosseini, S., and Moradi, G. R. (2020). Low-cost biodiesel production using waste oil and catalyst. Waste Manag. Res. 39, 250-259. doi: 10.1177/ $0734242 \times 20935174$

Tang, L., Xia, Y., Wu, X., Chen, X., Zhang, X., and Li, H. (2017). Screening and characterization of a novel thermostable lipase with detergent-additive potential from the metagenomic library of a mangrove soil. Gene 625, 64-71. doi: 10.1016/j.gene.2017.04.046

Tian, K., Tai, K., Chua, B. J. W., and Li, Z. (2017). Directed evolution of Thermomyces lanuginosus lipase to enhance methanol tolerance for efficient production of biodiesel from waste grease. Bioresour. Technol. 245, 1491-1497. doi: 10.1016/j.biortech.2017.05.108

Tran, D.-T., Chen, C.-L., and Chang, J.-S. (2016). Continuous biodiesel conversion via enzymatic transesterification catalyzed by immobilized Burkholderia lipase in a packed-bed bioreactor. Appl. Energy 168, 340-350. doi: 10.1016/j.apenergy. 2016.01.082

Tufiño, C., Bernal, C., Ottone, C., Romero, O., Illanes, A., and Wilson, L. (2019). Synthesis with immobilized lipases and downstream processing of ascorbyl palmitate. Molecules 24:3227. doi: 10.3390/molecules2418 3227

Ugo, A. K., Amara, A. V., Cn, I., and Kenechuwku, U. (2017). Microbial lipases: a prospect for biotechnological industrial catalysis for green products: a review. Fermentation Technol. 6:2.

Ulker, S., Ozel, A., Colak, A., and Karaoglu, S. A. (2011). Isolation, production, and characterization of an extracellular lipase from Trichoderma harzianum isolated from soil. Turkish J. Biol. 35, 543-550.

Unni, K. N., Priji, P., Sajith, S., Faisal, P. A., and Benjamin, S. (2016). Pseudomonas aeruginosa strain BUP2, a novel bacterium inhabiting the rumen of Malabari goat, produces an efficient lipase. Biologia 71, 378-387. doi: 10.1515/biolog2016-0057

Uppada, S. R., Akula, M., Bhattacharya, A., and Dutta, J. R. (2017). Immobilized lipase from Lactobacillus plantarum in meat degradation and synthesis of flavor esters. J. Genet. Eng. Biotechnol. 15, 331-334. doi: 10.1016/j.jgeb.2017.07.008

Valero, F. (2018). Recent advances in pichia pastoris as host for heterologous expression system for lipases: a review. Methods Mol. Biol. 1835, 205-216. doi: 10.1007/978-1-4939-8672-9_11

Vanleeuw, E., Winderickx, S., Thevissen, K., Lagrain, B., and Sels, B. F. (2019). Substrate-specificity of candida rugosa lipase and its industrial application. ACS Sustain. Chem. Eng. 7:19. 
Verma, S., Meghwanshi, G. K., and Kumar, R. (2021). Current perspectives for microbial lipases from extremophiles and metagenomics. Biochimie 182, 23-36. doi: 10.1016/j.biochi.2020.12.027

Vorderwülbecke, T., Kieslich, K., and Erdmann, H. (1992). Comparison of lipases by different assays. Enzyme Microbial Technol. 14, 631-639. doi: 10.1016/01410229(92)90038-p

Wang, J., Wu, Z., Zhang, T., Wang, Y., and Yang, B. (2019). High-level expression of Thermomyces dupontii thermophilic lipase in Pichia pastoris via combined strategies. 3 Biotech 9:62.

Wang, R., Wang, S., Xu, Y., and Yu, X. (2020). Enhancing the thermostability of Rhizopus chinensis lipase by rational design and MD simulations. Int. J. Biol. Macromol. 160, 1189-1200.

Winkler, F. K., D'Arcy, A., and Hunziker, W. (1990). Structure of human pancreatic lipase. Nature 343, 771-774. doi: 10.1038/343771a0

Xin, R., Khan, F. I., Zhao, Z., Zhang, Z., Yang, B., and Wang, Y. (2017). A comparative study on kinetics and substrate specificities of Phospholipase A1 with Thermomyces lanuginosus lipase. J. Colloid Interface Sci. 488, 149-154. doi: 10.1016/j.jcis.2016.10.058

Xing, S., Zhu, R., Li, C., He, L., Zeng, X., and Zhang, Q. (2020). Gene cloning, expression, purification and characterization of a sn-1,3 extracellular lipase from Aspergillus niger GZUF36. J. Food Sci. Technol. 57, 2669-2680. doi: 10.1007/s13197-020-04303-x

Yang, W., Cao, H., Xu, L., Zhang, H., and Yan, Y. (2015a). A novel eurythermic and thermostale lipase LipM from Pseudomonas moraviensis M9 and its application in the partial hydrolysis of algal oil. BMC Biotechnol. 15:94.

Yang, W., He, Y., Xu, L., Zhang, H., and Yan, Y. (2016). A new extracellular thermo-solvent-stable lipase from Burkholderia ubonensis SL-4: identification, characterization and application for biodiesel production. J. Mol. Catal. B Enzymatic 126, 76-89. doi: 10.1016/j.molcatb.2016.02.005

Yang, W., Xu, L., Zhang, H., and Yan, Y. (2015b). Characterizing LipR from Pseudomonas sp. R0-14 and applying in enrichment of polyunsaturated fatty acids from algal oil. J. Microbiol. Biotechnol. 25, 1880-1893. doi: 10.4014/jmb. 1506.06011
Yin, J., Li, G., Ren, X., and Herrler, G. (2007). Select what you need: a comparative evaluation of the advantages and limitations of frequently used expression systems for foreign genes. J. Biotechnol. 127, 335-347. doi: 10.1016/j.jbiotec. 2006.07.012

Zha, D., Xu, L., Zhang, H., and Yan, Y. (2014). Molecular identification of lipase LipA from Pseudomonas protegens Pf-5 and characterization of two wholecell biocatalysts Pf-5 and Top10lipA. J. Microbiol. Biotechnol. 24:619. doi: 10.4014/jmb.1312.12005

Zhao, J., Liu, S., Gao, Y., Ma, M., Yan, X., Cheng, D., et al. (2021). Characterization of a novel lipase from Bacillus licheniformis NCU CS-5 for applications in detergent industry and biodegradation of 2,4-D butyl ester. Int. J. Biol. Macromol. 176, 126-136. doi: 10.1016/j.ijbiomac.2021.01.214

Zubiolo, C., Santos, R. C. A., Carvalho, N. B., Soares, C. M. F., Lima, A. S., and Santana, L. C. L. D. A. (2014). Encapsulation in a sol-gel matrix of lipase from Aspergillus niger obtained by bioconversion of a novel agricultural residue. Bioproc. Biosyst. Eng. 37, 1781-1788.

Conflict of Interest: The authors declare that the research was conducted in the absence of any commercial or financial relationships that could be construed as a potential conflict of interest.

Publisher's Note: All claims expressed in this article are solely those of the authors and do not necessarily represent those of their affiliated organizations, or those of the publisher, the editors and the reviewers. Any product that may be evaluated in this article, or claim that may be made by its manufacturer, is not guaranteed or endorsed by the publisher.

Copyright (C) 2021 Yao, Liu, Liu, Jiang, Wang, Wang and Wang. This is an openaccess article distributed under the terms of the Creative Commons Attribution License (CC BY). The use, distribution or reproduction in other forums is permitted, provided the original author(s) and the copyright owner(s) are credited and that the original publication in this journal is cited, in accordance with accepted academic practice. No use, distribution or reproduction is permitted which does not comply with these terms. 